\title{
2020-Vision: understanding climate (in)action through the emotional lens of loss
}

\author{
Lisa Jones, Florence Halstead, Katie J. Parsons, \\ Hue Le, Ly Thi Ha Bui, Christopher R. Hackney \\ and Daniel R. Parsons
}

\begin{abstract}
We are the midst of a climate emergency requiring urgent climate action that is as yet unforthcoming both on the scale and at the speed needed. This article considers this current state of inaction and how we might understand the processes of attitudinal and behavioural change needed through the emotional framework of loss. These issues are further explored through the additional lens of the year 2020, a year of tumultuous social change created by the COVID-19 pandemic. The article draws parallels with and looks to learn from the ways in which the collective loss experienced as a result of COVID-19 may offer a sense of hope in the fight not just against climate change but for climate justice. The article argues that appropriate leadership that guides widespread climate action from all is best sought from those groups already facing the loss of climate change and therefore already engaged in climate-related social action and activism, including youth and Indigenous peoples.
\end{abstract}

Keywords: Climate change, activism, climate action, climate movement, climate justice, 2020, COVID-19, loss, emotion, hope, youth, social action.

Notes on the authors: see end of article.

(C) The author(s) 2021. This is an open access article licensed under a

Creative Commons Attribution-NonCommercial-NoDerivs 4.0 Unported License 


\section{Introduction}

The year 2020 has marked an important juncture as the year that measures set by the signatories of the 2016 Paris Agreement were due to take effect (UNFCCC 2020). Aiming to limit climate change driven global temperature rises, the Paris Agreement set out the responsibilities of all nations for urgent climate action to mitigate an existential threat posed to humans. In the lead up to COP26, the forum to share and check progress towards the goals of the Paris Agreement (scheduled for November 2020), young climate activists in particular have made clear their dissatisfaction with the lack of urgency and progress being made towards tackling this emergency, with this prompting the largest ever international climate change protests in September 2019 (Moeve 2019). Then, in the early months of 2020, the COVID-19 pandemic spread across the world, creating an unprecedented period of change. As many nations locked down and focused on the coronavirus, climate change was off the global agenda, the COP26 was postponed and the youth-led climate movement experienced significant disruption to their mobilisation. As the world now looks to transition through and out of the COVID-19 crisis, important questions are being asked about how we can 'build back better' in ways that are both fairer and more environmentally sustainable and consider the role of youth voice within this rebuilding effort (United Nations Environment Programme 2020).

In this article we focus on this culturally significant year of 2020, reflecting on the seemingly intractable issue of large-scale climate inaction in dealing with the climate emergency. The COVID-19 pandemic is without doubt a watershed moment that will become a part of defining popular discourse in terms of pre-/-post COVID-19. It also offers a unique opportunity to pause and reflect, to offer insight, and enable vision into what can be different. The pandemic has had an overwhelming emotional impact on many (Maddrell 2020), causing significant disruption to life as we know it. The now popular phrase of 'the new norm' (Lawson 2020) suggests it has replaced what went before signalling a loss of norms. It is therefore through this affective lens of dealing with imposed change akin to loss that we want to consider climate change inaction, drawing parallels with the current pandemic as we do so. We explore the challenges as well as opportunities this highlights as a means for understanding how to mobilise climate action over inaction. We focus on the ideas of Kübler-Ross (1969), whose initial work was developed within the context of death and dealing with grief.

Whilst applying this frame to our discussion, we recognise that not all societies deal with loss and grief in the same way and thus in drawing parallels between human loss and climate change in societies "where "endings", including death are "cultural taboo" (Moser 2020: 2), the article inevitably pulls towards explanations on climate inaction within the context of the Global North. Climate change is a global issue with 
problems of inaction permeating many societies, however we argue the overarching 'problem' of climate inaction is one created, and maintained, by the Global North and societies with 'climate/environmental privilege' (Norgaard 2012; Williams 2020) through systemic inaction. Utilising this lens, we unpack 'inaction' as we consider what this looks like in a broader global context. We examine the role of emotion in mobilising individuals into action, before looking to examples of leadership in this area, particularly focusing on those communities already being directly affected by climate change. But first, we focus on understanding the problem of climate change as one of climate (in)justice.

\section{Climate change as an issue of injustice}

We are in the midst of a climate crisis (IPBES 2019). With 2020 predicted to be the hottest year on record and 19 of the 20 hottest years occurring since 2001 (NASA 2020), the scientific community unequivocal in locating the reasons for this firmly with human activity (IIPC, 2021). Our reliance on burning fossil fuels as the primary power source for the global economy leads to excess heat being trapped within the earth's atmosphere, creating a range of problems including rising sea temperatures, melting permafrosts and ice sheets and an increased intensity of rainfall (IPCC 2018). The IPCC report (2018) demonstrated the need to cap global heating at 1.5 degrees above the pre-industrial baseline by 2030 and to move towards net zero greenhouse gas emissions by 2050 if we are to avoid irreversible damage (IPCC 2018). The picture is not a positive one and yet despite the overwhelming consensus from within the scientific community that human actions are culpable, the political will to seek change has been lacking (Willis 2020). At the most recent global climate summit, COP25, the nations of the world failed to reach necessary agreements to curb emissions (United Nations 2019). At the same time, the media (both mainstream and social media) remain beset with fake news and in an era of post-truth, fact and opinion converge, experts are dismissed (Willis 2020). Here the very real threat of climate change denial exists, with powerful lobbyists and interest groups maintaining a strong influence in politics, making the task of change nothing if not difficult (DeNicola \& Subramaniam 2014).

The dire consequences that climate change is, and will continue to have, on humans is multifaceted. Extreme weather events have seen a 3-fold increase since the 1960s, resulting in over 60,000 additional deaths per year (World Health Organization 2018). All social and environmental determinants of health; clean air, safe drinking water, sufficient food and secure shelter; are at risk (ibid). Between 2030 and 2050, climate change is projected to increase the prominence of malnutrition, malaria, diarrhoea 
and heat stress, leading to around 250,000 further deaths annually (World Health Organization 2018). Over 140 million people are predicted to migrate within their countries' borders by 2050 (Rigaud et al. 2018), solely because climate change has made their previous homes uninhabitable. Crops will fail to grow in the new conditions presented by climate change, sea level rise will swallow whole settlements, access to clean drinking water will cease, and other locations will simply become too hot to sustain human life. With these challenges, over 100 million additional people will be pushed back into poverty as soon as 2030 (Hallegatte et al. 2015). According to the World Wildlife Fund's 2020 Living Planet Report (WWF 2020), the global wildlife population has declined by $68 \%$ since 1970 . Biodiversity loss from deforestation and the cultivation of land for monocultures, plastic pollution, land degradation, exploitation of the Earth's natural and finite resources, water contamination and air pollution, to name but a few on an even longer list, are all putting our ecosystems under additional pressure and threatening biodiversity on both local and global scales (O'Connor et al. 2020; Peters et al. 2020).

The situation presented above is bleak for everyone, however the negative impacts of climate change are not equally dispersed and instead, countries in the Global South and otherwise disadvantaged groups are disproportionality affected (World Health Organization 2018). We use the term disadvantaged to categorise those who experience climate inequalities and bear the brunt of climate injustices; paying particular attention to the Global North/South divide and the demographic, socio-economic and political factors such as gender, race, age, ethnicity, religion, income and assets, access to public resources and involvement in public decision making; in governing the unequal distribution of negative climate impacts. The dynamics listed here are not an exhaustive list and there are many other contributing factors that predict an individuals' or communities' (dis)advantage. The climate crisis is thus particularly unjust in that the most vulnerable to its impacts are those least responsible for its creation (Robinson 2019; UNICEF 2015). As such, Sanson \& Burke (2020: 343) view the climate crisis as 'an issue of structural violence and intergenerational justice' which may lead to a breakdown of human rights and a 'climate apartheid scenario in which the wealthy pay to escape overheating, hunger and conflict, while the rest of the world is left to suffer' (United Nations General Assembly 2019: 10).

Under the premise that inequalities relating to demographic characteristics such as race, age and gender often present themselves through income and assets, Islam and Winkel (2017) suggest that disadvantaged groups, that is those who face climate inequalities, are: more exposed to climate hazards; more susceptible to damage caused by climate hazards; and have decreased ability to cope with and recover from climate damages. Put simply, 'the relationship between climate change and social inequality is characterized by a vicious cycle, whereby initial inequality makes disadvantaged 
groups suffer disproportionately from the adverse effects of climate change, resulting in greater subsequent inequality' (Islam and Winkel 2017: 2).

This correlation between climate (in)justice and wealth disparities is well documented elsewhere, whereby poverty is considered a key element in determining vulnerability to climate change (Gerrard 2016; Givens et al. 2019; Hallegate et al. 2015; IPCC 2018; Jorgenson et al. 2019; Rigaud et al. 2019). On an international scale, the most disadvantaged by climate change are poorer nations, often within the Global South, and Indigenous communities (Givens et al. 2019; Hallegate et al. 2015). Many of these regions lie in geographically high-risk areas that face increased risk from a rise in both flooding and drought. However, it is not their geographical location alone that puts them at a disadvantage. Positioning them as much more at risk than their wealthier counterparts, poorer nations are more likely to lack quality and accessible healthcare for all adequate information and warning systems, climate resilient infrastructure and developed mitigation and adaptation strategies/technology, positioning them as much more at risk compared to their wealthier counterparts (Hallegate et al. 2015).

Deemed to be one of the greatest threats posed by climate change, of particular concern to developing nations is food security (IPCC 2018). Often relying on small scale agriculture for both income and food, a loss of predictable weather patterns and an increase in frequency and magnitude of hydrological extremes in particular, will puts developing nations and their citizens at the epicentre of this challenge (IPCC 2018). It is no doubt that these changes will impact the poorest nations hardest, however the injustice is only fully understood when considered under the backdrop that collectively, the 10 most food insecure countries in the world emit just $0.08 \%$ of total global Carbon Dioxide $\left(\mathrm{CO}_{2}\right)$ emissions (Ware \& Krammer 2019). These nations, despite contributing so marginally to climate change, face much graver challenges than the world's biggest $\mathrm{CO}_{2}$ producers, and whilst developing countries with a high $\mathrm{CO}_{2}$ expenditure do exist, it is usually under the pretence of supplying inputs and labour for the West (Prell \& Sun 2015). Wealthier nations are in essence 'offshoring' their emissions and environmental degradation elsewhere (Roberts \& Parks 2007). These poorer nations, as theorised within the Ecologically Unequal Exchange Concept, act as both a tap and a sink for the rest of the world; as a point to extract resources and dispose of waste within the world's economic system of extraction, production and consumption (Givens et al. 2019). Such exploitation further exasperates the environmental and ecological risks that these countries face, which in turn increases their exposure and vulnerability to the negative impacts of climate change (ibid). Within country correlations between inequality and poverty are also apparent and are further nuanced by personal income and assets (and thus poverty), that too are compounded by social categories and identities such as race, age, social class and 
gender. These identities are intersectional; that is they 'work together to produce advantages and disadvantages across bodies and space, and ... do not act independently of one another' (Pellow 2016: 225).

For many years, climate change communication, particularly in the Global North, had a predominant disposition towards the science, utilising the 'polar bear on a melting ice cap' imagery with which most individuals are now familiar (Manzo 2010; Moser 2010). Over the years facts and figures made headlines, however the unjust impact this might have on humans was rarely communicated. Whilst how we communicate climate change to the public has been of academic interest since the initial communication methods in the 1980s, in 2018, a then 15-year-old Greta Thunberg, thrust a new angle upon the world as she made clear the injustices that climate change laid upon her and her peers as they critiqued adults' stewardship of the Earth (Bandura \& Cherry 2019). Striking from school to highlight her cause, she gained public and media attention and by 2019 the climate strikes had gone global, occurring every Friday under the now named \#FridaysForFuture. All acutely aware of how the current status quo was affecting their current and future worlds, countless environmental and Indigenous movements came to the forefront, whilst Extinction Rebellion stepped up their acts of civil disobedience. Environmental movements that had long existed in the Global South soon also built upon the school strikes, both adopting and adapting the approach to connect to their ongoing activities (CIVICUS 2020: 6). Climate injustices towards youth in particular, were now firmly in the public eye.

Youth (and their allies) began to mobilise their political power to highlight these injustices, with an estimated 6 million young people and their supporters from across the globe taking part in the largest climate strikes in history in September 2019 (Taylor et al. 2019). The youth voice, and hard to ignore visible evidence, was mounting and in response, governments across the globe made declarations acknowledging the climate emergency, whilst many major corporations committed to divestment from fossil fuels. Pledges to be carbon neutral surfaced from across the economic and political spectrum and the crisis increasingly became front page news (CIVICUS 2020).

For all of civil societies' successes in advancing the climate crisis on the political agenda and within the public eye, views on such forms of activism were often very divided with loud critics vocalising disbelief and discrediting youth's evidence (Trajber et al. 2019). International companies with an vested interest in maintaining the status quo channelled their finance into fake news that discredited the movements and climate science (Farrell et al. 2019), whilst public figures and politicians undermined the youth that took a stand (Pinheiro 2020). For example, counter-terrorism police in England placed Extinction Rebellion on a list of groups with extremist ideologies (Dodd \& Grierson 2020) and Brazil's president Jair Bolsonaro publicly branded Greta 
Thunberg as a pirralha [little brat] (Watts 2019). With an array of conflicting (mis) information available to the public, opinions about climate change and climate activism were polarised, seeing the public divided into various levels of concern, distress and action; rather than a homogenous group of citizens working towards the same cause. Nevertheless, regardless of the vast disparity of personal opinion, it would be fair to say that 2019 was the year when 'civil society pushed climate change into the headlines and made it part of everyday conversation' (CIVICUS 2020: 6).

The following year of 2020, however, brought the COVID-19 pandemic. As the world went into lockdown, the Climate Strikes were put on hold in aide of mitigating the virus and front-page news became nothing other than COVID-19 related. The climate emergency was seemingly pushed aside. The pandemic disrupted activist's personal lives and circumstances, obstructing progress and slowing momentum. Ways of working had to be adapted, with activism predominantly going online, exposing not only the opportunities for mobilisation through virtual means, but also 'digital divides and online power imbalances between dominant voices and excluded groups, and between the Global North and Global South' (CIVICUS 2020: 6). We return to this focus on climate activism later in the article in considering the future of the climate movement and how it can move forward through wider forms of mass mobilisation on climate action. We also return to 2020, a year of unprecedented change and consider the impact that this has had, and is likely to have, on the thinking through the future for climate action.

\section{Connecting emotionally: climate 'change' as loss}

In attempting to understand the difficulty in mobilising an integrated climate movement to date, and the overall widespread inaction on climate change, McAdam (2017) argues that affective dimensions on understanding social movements more broadly have often been underestimated. Coming from a social movement theory perspective, McAdam (2017: 201) notes that '... movement analysts have come to view heightened emotions not simply as a characteristic feature of emergent collective action, but as a necessary causal component of any explanatory theory [of social movements]'. He suggests:

In general, the reason grassroots movements are rare has more to do with subjective impediments to mobilization than with objective opportunities or the presence/ absence of mobilizing structures. Human beings are creatures of habit, deeply invested in the taken-for-granted routines, behavioral norms, and established worldviews that structure our lives. Emergent collective action almost always requires people to depart from those routines, violate those norms, and begin to act in accordance with new 
conceptions of ourselves and the world. As any seasoned organizer knows, getting people to do this is very hard. We tend to resist doing so even when the issue at stake is in our objective interest (McAdam, 2017: 199).

McAdam argues that for a grassroots movement to succeed, the mobilising emotions of anger and/or fear - at the injustice and perceived threat respectively - must combine with a hope that the injustice or threat can be remedied through collective action. Lacking these mobilising drivers means that it is highly unlikely that a movement will develop. Talking more broadly about social movements, McAdam highlights that it is when these 'mobilizing perceptions' come together with 'opportunities and organization' that collective action becomes possible. Talking specifically about climate change, McAdam suggests that 'concern over climate change has not been accompanied by the mobilisation of either of the two strong emotions, fear or anger, normally associated with movement emergence' (2017: 201). Thus, the subjective and affective orientation of individuals is perhaps where we may best understand the root impetus for collective (social) movements on climate change.

Climate change represents the biggest form of (un)imaginable loss to humans; at worst, the threat to life as we know it and our existence. It represents loss of certainty about what the future holds, a loss of confidence that we can simply carry on as we were and the potential for a loss of, most worryingly, of hope for the future. As we have already argued above however, affective responses to climate change have not yet managed to inspire and mobilise the wide scale social movements and/or commitment to action and social change required to address the advancing crisis. One area where humans do experience individual loss at its most extreme is in relation to death - both the anticipation of one's own and that of a loved one, and whilst death has a more 'clear end point' (Hobbs 2013: 147) 'change itself represents a loss of what was there before' (Hobbs 2013: 146), forcing us as 'creatures of habit' to 'depart' from and 'violate' the 'deeply invested in' and the 'taken-for-granted routines, behavioral norms, and established worldviews that structure our lives' (McAdam 2017: 199).

Emerging from the field of psychiatry through her work initially with terminally ill patients, Kübler-Ross (1969) theorised that there are five stages of grief that individuals experience on receiving the news of their impending mortality. These five stages are: Denial, Anger, Bargaining, Depression and Acceptance. These act as a framework that equips us with dealing with life and loss, with the model being one of the bestknown frameworks that attempt to understand the process of grieving. The framework is not without its criticisms, amongst them that it was not based on substantive empirical evidence and that explicitly labelling naming five stages might suggest that those who did not fit within these stages or such a journey that they were grieving incorrectly (Corr 2019). However, despite some perceived shortcomings, the framework has been widely used and adapted across various fields beyond psychiatry, 
evolving from its initial focus on death to a wide range of other situations involving a form of individual loss, trauma and/or significant change including, but not limited to the breakdown of relationships and estrangements, the loss or restructuring of work and routines, infertility, disclosures around sexuality and transgenderism and so forth (Coolhart et al. 2018; Gibson 2007; Parkes 1972; Sanders 1999; Savin-Williams \& Dubé 1998; Vickers \& Parris 2007; Wright 2011).

Perhaps unsurprisingly then, there is a growing body of work that focuses upon grief, loss and emotion as linked to climate change and environmental losses more broadly (Antadze 2020; Hobbs 2013). Moser (2020) offers an important summary of these, including work focused on climate grief - where people begin to mourn the losses to habitats, spaces, species and ways of life (Cunsolo \& Ellis 2018; Marshall et al. 2019), climate anxiety - the impact on people's wellbeing caused due to worrying about climate change (Clayton 2020; Phikala 2018) and 'solastalgia' - 'the distress that is produced by environmental change impacting on people while they are directly connected to their home environment' (Albrecht et al. 2007: s95) with Kübler-Ross' ideas having been influential within significant parts of this work. Running (2007), directly using the five staged framework as an analogy to make sense of the emotional responses of people to his work as a climate scientist, argued that most people started at stage 1 - Denial, either not believing science itself or that humans are at fault and argued people at this stage see no reason to disturb the status quo. Running (2007) argued that in his experience, many people jumped straight from stage 1 to stage 4 (Depression) whereas others moved to stage 2, Anger (often directed at him as the bearer of the bad news). They also displayed anger toward the idea of them having to change their lives as a means to mitigate climate change, an observation well echoed elsewhere within the field of climate science (Socolow 2012). This might, at least in part, explain some of the widespread anger and hostility directed towards Greta Thunberg. As a particularly prominent activist, Greta Thunberg often appears targeted as the messenger (McCarthy 2019) and frequently undergoes intense scrutiny aimed to discredit her messages; often via deeply personal and malicious denigration of her status as young person, a female and somebody with autism. Interestingly then, she too unequivocally exhibits and draws upon emotional responses including anger, however it is framed under a different light and instead shows anger directed at the lack of action on climate change (Martiskainen et al. 2020).

Following these initial two stages, Running (2007) argues that those who then proceed through the third stage Bargaining, are those looking for/clinging to any positives inferred within climate change that enable them not to have to embrace changes to their behaviours or lifestyles, such as celebrating warmer weather and the positives this might bring, including say reduced heating costs and energy consumption. Step 4, Depression, represents the shift in thinking and the associated feelings to 
understanding change is necessary but is deeply upsetting for many, especially in considering the enormity of the task ahead with Running (2007) saying that he himself often reverts to this stage on bad days. For Running, stage 5 Acceptance is the stage at which the problem is acknowledged and solutions are sought, although he adds the important caveat that for addressing climate change, the viability of alternatives need to be clear for all to see to enable 'hope'.

In building upon Running (2007), Wysham (2012) makes clear that stage 5 is often difficult to reach because the implications are so scary, but adds that:

We must accept this dreadful prognosis if we are to act appropriately. But acceptance does not mean that is all is lost. After years of working through these stages, I've discovered a new sixth stage: Doing The Work. This means taking courage from each other as we look this monster in the eye and fight side-by-side in the battle of a lifetime. Systemic change - not just light-bulb change - is what's required now. This must include everything from replacing the GDP as an outdated measure of progress to getting schools to teach climate science and arm the next generation with the facts.

Here, Running (2007) and Wysham (2012) are both working with the emotional response stages outlined by Kübler-Ross (1969) as applied to understanding the emotional journey individuals go through as they process the implications of change, and the disruption to 'normal life' (McAdam 2017). In adding the sixth stage, Wysham moves away from the function of the original stages within the Kübler-Ross (1969) framework because 'The Work' is not an emotional reaction as much as it is an 'action'. Whilst lesser well utilised than the original Kübler-Ross (1969) framework in most academic fields, the adaption of the model referred to as the Kübler-Ross Change Curve ${ }^{\mathrm{TM}}$ has been widely used in the world of business to both understand and manage more collective forms of loss and/or change, most notably organisational change (EKR Foundation, n.d.). Within the Kübler-Ross Change Curve ${ }^{\mathrm{TM}}$, the stages of grief first developed by Kübler-Ross (1969) are seen as the emotional responses to and reactions regarding the news of change and are seen as 'defence/coping mechanism to change, loss and/or shock' (EKR Foundation, n.d.). Jalagat (2018: 2), highlights the four 'stages of change' present in Kübler-Ross' Change Curve ${ }^{\mathrm{TM}}$ with each stage encompassing the emotional reactions to this change, loss and/or shock. Captured within each stage is the present 'state' of change whereby 'the idea is that insights provided at each stage reduce the change impact and move individuals from negative to positive stages in an upward curve towards transformative sustainable change' (Ramos-Volz 2018: 145). The first state is that of 'status quo' where shock and denial are the reactions to the news of significant change/loss that is experienced as a 'traumatic situation' (Jalagat 2018: 2). The second state of change is 'disruption' where anger and fear are the typical reactions of those experiencing the changes and there is realisation that their lives are about to undergo significant changes and the negative 


\section{Wave of Change in a Sea of Emotion}

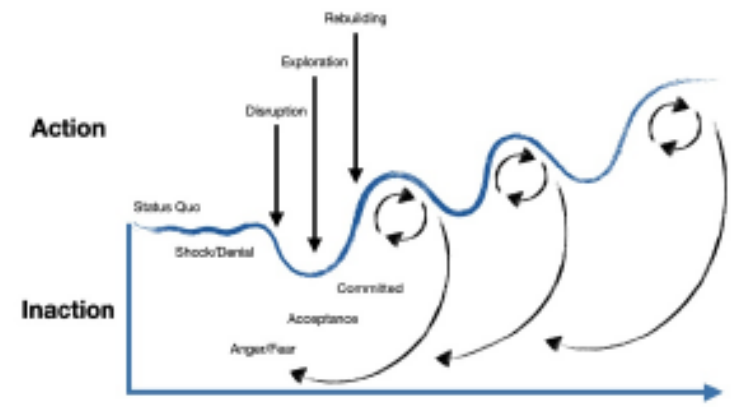

Figure 1. Wave of Change in a Sea of Emotion - adapted from Kübler-Ross (1969).

implications are amplified in providing motivation for resisting (Jalagat 2018). Stage 3 , 'exploration' is where people become able to 'accept' that change is happening and start to explore future opportunities. Jalagat (2018: 3) sees this stage as being the 'turning point for people to slowly discover the significance of change' before then moving into the fourth and final state of change, 'rebuilding', whereby individuals have reaction moves to 'commitment'; a commitment to engage and shape their response to the change in a positive way. In our view, incorporating the ideas from Kübler-Ross' Change Curve ${ }^{\mathrm{TM}}$ allow us think about that relationship between emotions and our commitment to change. However, we would argue that rather than a singular curve of change, to understand the relationship between emotions and change linked to climate action, this might best be understood as resembling a wave as we have depicted in Figure 1.

Here we have focused on attempting to understand the implications for engaging in various forms of action, with the initial first and second 'state' of change ('status quo' and 'disruption') representing inaction, whilst the third and fourth 'state' ('exploration' and 'rebuilding') signalling 'turning point[s]' (Jalagat 2018: 3) towards action. In this way, Wysham's (2012) addition of the sixth stage 'The Work' to Running's initial use of the five stages outlined by Kübler-Ross (1969) is also encapsulated in 'commitment' to 'The Work' needed to rebuild. However, in moving to a more continuous wave of change embedded within what we see as a moving sea of emotion (Figure 1), we recognise that this is a messy process with many points for which those on that emotional journey of change can face further emotional disruptions that may need to explore and rebuild from.

We propose that these exploration and rebuilding stage[s] are significant in understanding the emotional journeys already travelled by those individuals involved in climate activism and social action; already committing to the enormous task of 
'rebuilding' in its various guises. In fact, an important part of 'The Work' involved in this 'rebuilding' state is to get as many people to traverse a similar emotional journey to theirs if they are going to tip people out of the first two stages and reach their turning points but the question remains; how will this happen given the general widespread inaction despite the almost unanimous scientific consensus on the urgent need for action? Returning to McAdam's point (2017: 194) that to mobilise people into a movement, '... at a minimum, people need to feel both aggrieved about (or threatened by) some aspect of their lives and optimistic that by acting collectively they can begin to redress the problem...' In trying to understand this lack of mobilisation on climate, despite the existential threat, McAdams (2017: 201) argues:

Concern over climate change has not been accompanied by the mobilization of either of the two strong emotions, fear or anger, normally associated with movement emergence. Two factors I have mentioned above-lack of identity ownership and extended time horizon - help us understand why this is the case. First, relative to other issues, few of us feel a strong identification with the issue of climate change, and strong emotion requires just this kind of identification.

He continues:

The extended time horizon that people associate with climate change also has affective implications. As long as we can persuade ourselves that the worst effects of climate change lie in some relatively distant future and that we still have time to minimize their damage, our fear of climate change is more likely to be of a dispassionate, intellectual nature than the more visceral fear that catalyzes action.

It is hard to disagree with McAdam's observations here as being highly significant in accounting for the lack of widespread action at a grassroots level. Moser (2020) additionally argues that pushing the urgency of climate change is unlikely to be a vote winner for most global political leaders, meaning agreed and meaningful top-down action is unlikely without the significant pressure that can result from social movements. Climate change then has perhaps just been too big (and philosophical), too impersonal to us as individuals, and perceived to be too far in the future to trigger the personal shock and fear needed to even disrupt the 'status quo' of people's lives. Under this guise, the vision of enough people actively engaging in exploration and rebuilding has seemed, depressingly up until now, an almost impossible feat.

\section{The year 2020 - collective grief and loss}

2020 was, in the most simplistic of terms, a tumultuous year. A global pandemic that has caused mass disruption to life as we know it across the globe. David Kessler, 
compared the feelings people were going through as akin to dealing with loss and grieving in an interview with Harvard Business School that went viral in March, as much of the world faced lockdown (Berinato 2020). Kessler said:

...we're feeling a number of different griefs. We feel the world has changed, and it has. We know this is temporary, but it doesn't feel that way, and we realize things will be different. Just as going to the airport is forever different from how it was before 9/11, things will change and this is the point at which they changed. The loss of normalcy; the fear of economic toll; the loss of connection. This is hitting us and we're grieving. Collectively. We are not used to this kind of collective grief in the air (Berinato 2020).

He explains how the emotional responses people were experiencing followed the five stages of grief from Kübler-Ross' (1969) framework:

There's denial, which we saw a lot of early on: This virus won't affect us. There's anger: You're making me stay home and taking away my activities. There's bargaining: Okay, if I social distance for two weeks everything will be better, right? There's sadness: I don't know when this will end. And finally, there's acceptance. This is happening; I have to figure out how to proceed. ... Acceptance, as you might imagine, is where the power lies. We find control in acceptance. I can wash my hands. I can keep a safe distance. I can learn how to work virtually (Berinato 2020).

Kessler's reflections on the experience of collective grief here is of particular significance to us in this article. Whilst Kessler's point, that the pandemic is 'temporary', of course does not hold true of climate change, if we can even be certain of the temporariness of the pandemic, discussing the 'anticipatory grief' the pandemic has created, Kessler opens up the parallels further:

... we're also feeling anticipatory grief. Anticipatory grief is that feeling we get about what the future holds when we're uncertain. Usually it centers on death. We feel it when someone gets a dire diagnosis or when we have the normal thought that we'll lose a parent someday. Anticipatory grief is also more broadly imagined futures. There is a storm coming. There's something bad out there. With a virus, this kind of grief is so confusing for people. Our primitive mind knows something bad is happening, but you can't see it. This breaks our sense of safety. We're feeling that loss of safety. I don't think we've collectively lost our sense of general safety like this. Individually or as smaller groups, people have felt this. But all together, this is new. We are grieving on a micro and a macro level (Berinato 2020).

The newness of this grief on simultaneously 'a micro and a macro scale' offers us an insight into something not previously possible in exploring people's seeming reluctance (or inability) to comprehend the urgency of addressing climate change. Returning to the Kübler-Ross Change Curve ${ }^{\mathrm{TM}}$ and our wave of change, COVID-19 has created, or forced rather, a 'shared' experience of change and disruption to the status quo, even 
if the impacts are felt very differently and unequally (Krieger 2020b.; Maddrell 2020). The sense of anticipation of the devastation of something bad that we cannot see but we know is there draws clear parallels between climate change and the COVID-19 pandemic (Manzanedo \& Manning 2020). As Kessler notes earlier, the pandemic represents that things will be 'forever different' and that 'this is the point at which they changed' (Berinato 2020). Of course, 'loss' of any kind is often deeply unpleasant and painful. However, as within the Kübler-Ross Change Curve ${ }^{\mathrm{TM}}$ and our wave of change, it might be suggested that after experiencing the low points following the comprehension of loss, when there is acceptance, there comes the opportunity for exploration to enable commitment to rebuilding. We therefore now consider what we can learn from the way this collective grief is being experienced and how notions of rebuilding are being utilised to talk about different imagined futures - and importantly, what this means, and could mean, to, and for, the climate movement.

\section{A time to pause and reflect - to hope and to act}

Whilst the long-term impacts of the pandemic are still to be felt, what 2020 has offered is the opportunity to pause and reflect on the world as it was and how it could, and should, be in the future. This 'pause' creates a space and an opportunity to consider how things can be different. For instance, a report detailing a public consultation in the UK on what society should look like as we come through COVID-19 in UK says that the pandemic 'transformed the national mood' (Reset 2020: 13), and that people across all walks of life had a clear vision of wanting a 'kinder, more united, fairer and greener' society. This renewed vigour for supporting vulnerable people, wealth redistribution and transformative policies is, Zamore \& Phillips (2020) argue, echoed globally. The notion of rebuilding has gained significant traction and can be seen as represented in calls to 'build back better' in relation to economic and social recovery - this meaning to rebuild in ways that are fairer and more inclusive but also extending this to considerations of environmental sustainability and tackling climate change (OECD 2020). As many Global North countries imposed national lockdowns in March 2020, business as normal halted, the status quo was disrupted as many industries and sectors paused and most global air travel was temporarily grounded as the streets of towns and cities across the globe emptied. Millions of people watched on as social media was replete with images and videos of how 'nature' and the planet responded without the polluting influences of humans and intimated that another way was possible (MacDonald 2020; Brunton 2020). At the same time, the pandemic was raising awareness of global social and economic inequalities as it became clearer how the impacts of the virus were unequally and disproportionately affecting poorer nations (Maddrell 2020). The pandemic also highlighted (and for many exposed) 
inequalities within more prosperous nations, in particular, the disproportionate impact of COVID-19 on poorer communities and Black and Brown people (CIVICUS 2020; Krieger 2020b). In the UK, we also saw how those previously regarded as 'low skilled and low paid' be reclassified as 'key workers' during the pandemic, given the important role of those within social care, alongside keeping food and essential supplies manufactured, distributed and sold. However, as a result, these key workers were exposed to greater risk of catching the virus (Haque et al. 2020; Lally 2020).

In the midst of the pandemic, the year 2020 also saw significant social unrest and large-scale activism across many countries in the Global North in connection to the murder of George Floyd in the US and the Black Lives Matter (BLM) movement. In many respects, this marked an important juncture for considering the future of collective action and activism on climate change and to consider what we may also learn from such events and the BLM movement in particular. Whilst at first glance, the BLM movement may not seem directly related to climate justice, it illustrated 'the relevant mobilizing emotions are anger at a perceived injustice, or fear at a perceived threat, and hope that the injustice or threat can be redressed through collective action' noted by McAdam (2017: 194) and added to a heightened awareness of the injustices within society, including those that are environmental and climate related, amongst the general public. Whilst connecting the BLM movement and climate change injustices is not new (Mersha 2018), social and online media increasingly became saturated with posts and articles by people connecting systemic racism and climate/environmental injustices (Lakhani \& Watts 2020; Thomas \& Haynes 2020). Many climate activists whom had taken their activism online in the wake of coronavirus began to post about these links, some even recognising and highlighting their own privileges in activism when white (and/or perceived to be) (Jones 2020; Margolin 2020). A period of deep and critical self-reflection took place, perhaps somewhat facilitated by the space and time that the pandemic created to do so, and whilst these links had of course been made by many long before the Climate Strikes and the BLM protests, these movements thrust them into public viewing. However, for all of the noise and positive progress reported by these movements, they still equate to a subculture. They are made up of a mix of those directly impacted by the injustices, most notably Black and Brown people, Indigenous peoples and youth, and though quite literally millions have both led and participated in these movements, it still only equates to minority of the world's population.

What the pandemic has provided, if nothing else, is a collective reference point to utilise in explanations for what large scale disruption climate change is going to continue to have on our everyday lives and our taken-for-granted routines and norms. The experience of collective grief as noted by Kessler and the unique insights the 
pandemic offers into simultaneous 'micro and macro' grief (Berinato 2020) offers those attempting to contextualise the more abstract, macro scale of climate change that often seems so implausible to compute as something that will increasingly be experienced at that micro, individual level. It has also further highlighted concerns about 'climate apartheid' as the ability to respond to (and flee from) the pandemic was significantly affected by wealth inequalities (Ki-Moon \& Verkooijen 2020). The 'pause' and disruption to the status quo has of course also offered that space to ask important questions about how we begin to 'build back better', including creating a more sustainable world and tackle climate change. Perhaps in part driven by the direct parallels that unflinchingly link climate change, and continued human impact on biodiversity, with the likelihood of both increasing frequency and severity of future pandemics (OECD 2020).

In responding to the pandemic we have also witnessed how most governments and most people have 'acted' in a personal capacity in light the growing evidence-base - in wearing masks, maintaining social distance, following guidance to prevent/mitigate the spread of the virus (Manzanedo \& Manning 2020) and the point is already being made that 'the world must now urgently adopt the same approach to the existential challenge of climate change' (Robinson \& Reddy 2020). However, COVID-19 also reaffirmed just how unprepared the world was for a global emergency. Be it COVID19 or climate change, the inadequacy of existing structures limits progress in mitigating the catastrophic impacts. Whilst countries across the globe have risen to this challenge in varying ways, many have faced third and fourth waves of infection spikes and lockdowns, crippled by the social and economic impacts and have contributed to a global death toll exceeding 4.5 million (as of September 2021). Global leadership in handling emergencies was clearly on show:

The pandemic exposed many of these political leaders as lacking, as they indulged in grandstanding, fostered division, manipulated public opinion, manoeuvred for political gain and seized opportunities to further suppress struggles for justice and rights. The leadership styles that proved more effective were those that respected scientific advice, prioritised the needs of the most vulnerable, understood the need to communicate honestly and sought to preserve the best possible balance between public safety and hard-won constitutional freedoms (CIVICUS 2020: 7).

Of course whilst most people engaged in forms of individual action, others have reacted angrily, with many of these in denial about the (albeit still emerging) science (Wilson 2020; Friedman 2020) and have resisted the need for change to their takenfor-granted routines, stuck we might say in stage 1 of the change curve with many others feeling 'pandemic fatigue', by the ongoing nature on the pandemic and continued disruption to their lives (Roberts 2020). Likewise, the often angry All Lives Matter mobilisation that aimed to deny the injustices experienced by Black and Brown people 
and resistance around the need for change exemplifies the challenges facing attempts to mobilise broad base support for important social movements (Edgar \& Johnson 2018). Whilst for the most part, such counter movements represent minority factions, they do remind us that those who cannot see the pertinence in their own lives and/or those who feel threatened, as is the case with the hostility to notions of white privilege has highlighted (Murray 2020), are likely to be amongst those most reluctant to accept change (McAdam 2017). This type of vested interest with a strong desire to preserve the status quo and resist societal change in relation to climate change cannot be underestimated. Most notably, this is exemplified by the global, multibillion pound fossil fuels industry and the force powerful political lobbying that goes on in many nations in their interests (Hein \& Jenkins 2017). Furthermore, whilst there have been clear historical examples of huge scale societal change following catastrophic events (for instance, the introduction of the welfare state across many nations following World War 2 - see Obinger et al. 2018), there must rightfully be some caution in placing too much emphasis on any certitude about the longevity of this wave of optimism, or that this translates into action. For instance, McAdam (2017) notes that the raised awareness of climate change resulting from having directly experienced extreme weather events is only short term. Moreover, there are already concerns that even with the large-scale mobilisation and momentum of the BLM movement, the systemic racism and deep-routed inequalities stay intact with 'change' being limited to important, but nonetheless more symbolic cultural gestures (Malik 2020), or as Fraser (1999) would argue, only the representational forms of injustice are addressed without redistributive aspects. Nevertheless, and most significantly, these important events in 2020 have already given something extremely powerful to both individuals engaged with climate action and within the climate justice movement more broadly - that of hope (Jafry 2020; Larsson 2020; Solnit 2020). We return to this important notion of hope shortly. But first we begin to consider the task ahead of capitalising on what we have learnt in 2020 and applying to how we mobilise action by first of all, being the bearer of bad news.

\section{Communicating (and contextualising) the bad news}

There is clear evidence that the majority of people in many different countries believe that climate change is happening and is a major threat to their country (Fagan \& Huang 2019). However, as we have illustrated throughout, there is currently widespread inaction on addressing climate change or mitigating against its impacts. However, as McAdam (2017: 200) notes, 'how a movement researcher records the objective relevance of an issue for a given individual counts for little if that person 
feels no subjective identification with it ...' This has always been an enormous challenge for mobilising climate action. This abstracted notion of climate change not only enables a disconnect between the micro and macro, thus creating a space for cognitive dissonance to thrive, but it also locates the solutions and routes to mitigating the damaging effects of climate change in the hands of scientists (Gifford 2011; Rommetveit et al. 2010). Through the lens of 2020, there is a collective experience to draw upon to 'frame' the problem (Tannen 1993; Morton et al. 2011) and those who see the urgency of a need for action should be looking at the most effective ways to converge the macro (global) and the micro (individual) in enhancing the communication of climate change. Earlier we highlighted the injustices of climate change and foregrounded the way in which climate change impacts on humans and its unequal nature. Many now contend that couching the message in this way is central highlighting the human rights and social justice aspects of climate change (Robinson 2019). Additionally, the term 'climate change' itself can be argued as problematic as it is non time-specific, it future-orientated and enables people to relegate the issue to one to address at a later state (McAdam 2017). Language is important and discussions should 'frame' the message clearly, for example, the phrase 'climate emergency' suggest the need for immediate action. These views are not new, but the general language used through most mainstream media communication channels and political discourse in the UK for instance as well as other countries, still focuses on 'climate change' as the issue, with a few exceptions (Zeldin-O'Neill 2019). Instead, the messaging needs to be personalised and relevant to the here and now; people need to understand what the climate crisis means to their everyday lives. There are clear parallels with the impacts of COVID-19 on lives and livelihoods and importantly, messaging needs to be able to detail what is stake for the individual and the threat to their everyday lives that climate change represents. In the first section of this article, we briefly outlined the human costs of the climate crisis - the likelihood of increases in health issues, food shortages and so on. The pandemic enabled some insight that would help contextualise these issues. In the UK for instance as with many other countries, access to many food items and other essentials were limited as transportation, manufacturing and supply chains were temporarily disrupted and empty shelves and forms of rationing were introduced (Smithers \& Collinson 2020). For many richer nations, this experience is not a familiar one in recent history but does offer an important contextual framing device that could act as a resource to situate the macro context of climate change within the micro context of individuals' everyday lives.

The realities of the climate crisis and what future climate projections indicate are upsetting. In order to understand that we need change as a society, the message of the personal significance and urgency of this is imperative. In returning to Kübler-Ross' framing, the status quo must be disrupted to initially force people to accept the need 
for change and move from the state of inaction into action. Whilst people remain unaware of the severity of the situation and the urgent need for action, the status quo will remain intact and without concerted global governmental action, the climate movement will not be able to make the progress it needs. The above tactics of careful wording and personal relevance, help ensure that individuals understand the loss that is required to experience the various stages of change. Finally, the delivery of the bad news on the climate crisis must be 'framed' with a clear sense of hope and optimism (Morton et al. 2011). There exists a need to take individuals on a change journey of understanding the problem, which can often (though not always) take people to a low point, before exploring the opportunities for rebuilding. Whilst such change journeys can be seen as embedded into established climate leadership programmes (for example, the Climate Reality Project 2018) this needs to be framed from the perspective of possibility, that is, what is to be gained, not just what is to be lost (Nabi et al. 2018). How this bad news is communicated is also, of course, multifaceted. The delivery of knowledge and 'facts' based around the issues, even if they are focused on humans and made contextually relevant to people, will not work for everyone and therefore other avenues of communication must be considered, kept open and explored - for instance, through use of the arts (Cozen 2013; Roosen et al. 2018).

Whilst we need to 'individualise' the bad news to make it subjectively real and relatable in people's lives, we need to 'collectivise' the response (Climate Reality 2020; McAdam 2017). People need to understand that once they accept that change is needed and that they themselves can engage in, importantly meaningful, forms of change (including around values and behaviours) and they are not alone in exploring what needs to be done and the committing to change. Importantly, 'action' itself needs to be demystified and made accessible so that people are able to fully understand what can be done and what role they have to play in this. Or put another way, they need to have confidence that their action can contribute towards making a difference (Gifford 2011; Lorenzoni et al. 2007) and, in the words of Rommetveit et al. (2010: 150), that there is 'no solution to the issue without the radical involvement of citizens'. We now move on to focus on exactly this, understanding and unpacking what action looks like and the role all citizens can have before importantly moving on to look at whom we might look to for leadership.

\section{Unpacking 'action' for change making}

Once citizens understand that change is urgently needed, they then need to understand what they can do, developing a sense of agency linked to tangible actions. This is an important facet in mobilising people (McAdam 2017). In discussing climate change, a 
range of terms are often used, often interchangeably, to denote the actions of those engaged in such work (whether individually or collectively) including 'social action' and 'activism' alongside notions focused around 'social movements' (Staeheli et al. 2013). All of these terms denote being engaged in activities and/or practices with a focus on attempting to create and steer change within some aspect of society - as a response to some form of perceived shortcomings. However as is often the case, the terms used to describe and identify this body of people engaged in similar works are not neutral, have a history and come to be viewed in particular ways that have particular connotations. In what follows, we spend some time unpacking these terms within the context of climate change. We navigate the different elements of climate action as important layers of a broader social movement beginning by first focusing on the notion of activism, a term we would argue, can be perceived somewhat negatively.

\section{Activism}

According to the Oxford English Dictionary (2020), activism is defined as 'the use of vigorous campaigning to bring about political or social change' with an activist defined as a person engaged in this. Activism then is rooted in a belief that there are underlying structural, political, social and/or economic problems in need of redress (Ojala 2015). However, understandings of activism and what it means to therefore be 'an activist' have increasingly been viewed as 'dirty words' (Parsons 2016). In many societies, activism, and thus activists, have become seen as at best, a nuisance, at worst, hostile, aggressive and deviants (Lindblom \& Jacobsson 2014). In keeping with the negative perception of activism in many other key areas, climate activists are also likely to be viewed negatively, often seen as 'militant', 'overreactive' and 'selfrighteous', pejoratively stereotyped as outside of societal norms and values with regard to their views and lifestyles, often caricatured for instance as 'tree huggers' (Bashir et al. 2013: 617) leading to concerns that such negative perceptions can actually deter change rather than creating it, particularly by putting people off engaging in change themselves. There has also been a growing tendency to see climate activism as synonymous with engaging in forms of deviant and dangerous behaviour (Reis 2020). For instance, Extinction Rebellion, the UK-based group committed to civil disobedience that has been overwhelming peaceful are almost routinely castigated and were recently labelled as an 'extremist' alongside Greenpeace in a document produced by UK anti-terrorist police (Dodd \& Grierson 2020; Hilton 2019). As activism is always about trying to enact change and thus creating a disruption to the status quo, it is perhaps unsurprising that such activism is often viewed suspiciously, especially by those in power. This is a seemingly rational response from those who wish to preserve the status quo, especially when traditional activism has been the driver of so much 
social change, for instance the civil rights movement in the US, the fight for universal suffrage and changes to equality laws and policies across many countries. Even where seeming gains are later lost, such as in relation to the 2010 Arab Spring, activism can and often has led to social change and it is important to note here that in some nations, (climate) activism is not permitted/illegal and can be dangerous (Middeldorp \& Billon 2019). Throughout 2019 climate activism began to make a mainstream impact, with the biggest ever international demonstrations focused on climate change, whereby it was estimated that over 6 million people, led by youth made their voices heard (Cagle 2019; Godin 2020). Whilst this mass mobilisation as part of the \#FridaysforFuture and the school strikes for climate has attracted many supporters, it has nevertheless been framed by some political leaders and media outlets as moving beyond 'dutiful' through 'disruptive' and migrating into 'dangerous' forms of dissent in posing major challenges to the status quo, especially in seeing youth exercise their political agency outside of the normative political structures (O'Brien et al. 2018). The most 'dangerous' forms of dissent in the Global North for instance, are those that move beyond calls for an urgent transition towards carbon neutrality and instead question the premise of neoliberal capitalism and its compatibility with the goals of sustainability (Klein 2014). Nevertheless, the message being delivered by youth; that change was desperately needed and that our children's and their children's futures are dependent on this, was coming through as it was being widely reported and increasingly discussed (Bandura \& Cherry 2019).

The COVID-19 pandemic has of course had significant impacts on youth climate activism and there are serious concerns that this message has been side-lined as the world has moved both its focus and its efforts to the pandemic (Cockburn 2020; Poidevin 2020). Whilst these concerns are real, there are also important lessons emerging out of the pandemic in relation to climate action and we return shortly to this alongside how we can draw hope from the youth-led climate movement in particular. Many argue that the need for such activism has never been greater (Robinson 2019; Willis 2020) and thus there is an important role for not only the continuation but also for the growth of activism in facing the climate crisis, particularly in trying to assert pressure on the political leaders in many Global North countries, that have high carbon emissions. There are clear challenges here, not least in how to move away from the negatively perceived image of 'activists' as deviant and dangerous, especially when it suits the vested interests of the status quo, giving them perceived justification to ignore these voices when presenting activists in this way (as outside of normative structures). However, it is important to recognise that 'traditional' activism is not the only type of action that people can, and already are engaged in, as part of an inclusive and broad-based climate movement. 


\section{Social action}

Social action is a broad term with a long history as a concept primarily within the discipline of Sociology (Parsons 1937; Ekström 1992). It captures a diverse range of actions, activities and practices that people might engage in either as individuals or as a collective that focus directly on creating positive social change. Such social action may be driven by either a top down, institution and/or government, shaped agenda, or can emerge from grassroots, community-based, movements. The UK government, for example has embedded social action, and forming a generation of climate ambassadors, at the heart of its 25-year environment plan (DEFRA 2018) and likewise, international NGOs such as the UNs International Year of Volunteers program illustrate this in action (Taylor-Collins et al. 2019). Whilst there is an important role for such top-down social action, McAdam (2017), outlined above, stresses the importance of grassroots movements for seeking a more meaningful and systemic style of change. This is particularly the case given that many such organisations leading topdown initiatives derive their funding from governments and are thus dependent on those structures remaining intact for their own existence. McAdam argues 'as such, they are typically loath to jeopardize their standing in this structure by engaging in the forms of sustained disruptive action that are the hallmark of successful grassroots struggles' (McAdam 2017: 199). Forms of grass-roots social action here would include varied and diverse forms of activities evidenced globally. Their aims might be linked to addressing particular local issues linked directly to climate change and environment-related elements for instance in relation to land adaption and mitigation strategies (Irlbacher-Fox and MacNeill, 2020) one such example being planting mangroves in coastal Vietnam (Powell et al. 2011; Tri et al. 1998).

Social action and 'activism' are not mutually exclusive and instead are highly interrelated (Staeheli et al. 2013) especially given the often shared goals, particularly in regard to climate justice (Walker 2020). Willis (2020) makes an important and compelling argument that what is really needed to help influence political processes to take climate action are more deliberative and democratic processes, whereby citizens and politicians talk through the issues around climate change and what can/might be done. Willis (2020: 93) argues that 'people are concerned about climate, but uncertain about what can be done about it' and a shift in thinking in politics that foregrounds discursive encounters including citizens and leaders as opposed to one off 'assembly-style' activities is a mechanism for action leading to change. Localised mechanisms are likely to be especially important in political systems that have political representation at a local level (for instance, the UK and the US). We would suggest that whilst this is an important role that all citizens can engage in, there is perhaps also an important role to be played here by those already engaged in forms of social action 
or even the more 'traditional' activists in creating these important discursive spaces that enables citizens and leaders to be brought together to discuss influencing change at national/systemic levels. Such spaces can also begin to enable citizens to understand the role in which they can play in such collective endeavour as individuals, and additionally in terms of their own habits and behaviours (to which we turn shortly), thus highlighting the significance of highlighting the multi-phased nature of possible action.

\section{Individual action}

Agency and a clear sense that we can all contribute towards making a difference in the fight against the climate crisis is central in mobilising action (McAdam 2017). If people do not believe they personally can make a difference, there is no reason for them to believe that they have to change if change is out of their hands. Act Now, the United Nations' campaign for individual action on climate change and sustainability, launched in 2018 with a clear focus on highlighting how we can all make positive changes to our everyday practices and habits. Framed as 'start with ten simple actions', the significance was in engaging people with clear and easy changes focused around reducing both personal energy use and consumption - such as 'unplug', 'drive less', 'bring own bag', 'plant-based meals' (United Nations 2018). Whilst of course these changes at an individual level might seem insignificant and alone cannot tackle the problem, they challenge taken-for-granted practices at the heart of many societies, particularly in the Global North and our reliance on carbon that we often invisibly consume (Sanson \& Burke 2020) these small actions act as important steps into taking climate action. Taking these steps further, others have also advocated the important role citizens can have in exerting economic pressure on the financial institutions that invest in fossil fuels by divesting their personal money from banks, insurance and pension companies, and making the reason for such divestment clear (Ayling \& Gunningham 2015). However, as Willis (2020) notes, the 'personal is political' and she argues that these actions become more effective if we talk about them and influence others, speaking out (as well as listening) to others to 'spread the message'. Lastly, Willis argues that being 'good climate citizens' should, wherever possible, involve engaging in the political process and exerting pressure, whether that be through traditional forms of activism such as protest and/or the more deliberative forms of policy (Willis 2020). 


\section{Climate action as a movement}

The three broad 'types' of climate action outlined above, as we have illustrated, are intimately interrelated. We have referred to them as activism, social action and individual action although we might have easily referred to each as different forms of activism as others have previously (O'Brien et al. 2018). We are mindful of the (often unfair) negative perceptions of activism and the importance of being able to more broadly mobilise people into action globally, including in places where activism is not permitted/illegal. Irrespective of semantics, the three 'types' of action all aim to bring about change. Whether that be small, individual changes; exerting influence over national and international policy and practice and/or everything in between, change is the common goal regardless of scale. The importance of connecting the individual and the collective, the micro and the macro, are central because 'change' has to be systemic and wide-reaching (Sanson \& Burke 2020). Willis (2020) also highlights that change of this kind has to be political with people acting as 'good climate citizens' as change is going to require government intervention and change of this magnitude cannot be done through stealth but instead has to be embroiled within a 'a story of transformation' (p. 94) framed around both a positive, and importantly, a possible vision. As we have argued throughout the article, the story underpinning the need for action and its goals have to be 'an appeal to the heart' (Willis 2020: 96) and able to invoke emotional responses because the appeal to the head, which in this case would be the messages couched within the language of science, have has thus far not managed the forms of mass mobilisation into action required. This is especially important in the current political climate of growing right wing populism and increasingly heavy authoritarian overtones in several carbon emission-heavy countries (Wodak \& Krzy anowski 2017), where emotion has often been successfully mobilised to distance 'normal people' from the science of climate change (Lockwood 2018). Thus, as we argued in the previous section, the 'problem' of climate change needs to be delivered in a way that is two-fold. Through stories of injustice and its impacts on people, both oneself and the injustice of 'others', in ways that evoke a collective sense of loss with the framing of action equally needing to be affective, focusing on what can be gained by making these changes through stories that resonate with people in ways that evoke hope.

\section{Mobilising climate action: hope and horizontal leadership}

In the previous sections we have argued that in order to mobilise climate action, emotion and affect are central in both ensuring citizens understand that change is 
needed and also that they can play an important role in to enact meaningful change. Underpinning these are the notion of hope - hope that it is not too late and that something can be done about it, alongside hope that individuals can have a meaningful impact by engaging with change within their own lives. Hope is an important emotion because hope offers empowerment and faith in a better future (Lindroth \& SinevaaraNiskanen 2019) and a form of 'anticipatory consciousness' about a future of unknown possibility (Bloch 1986). Hope is especially central in attempting to mobilise action on the climate crisis because without it, the contemplation of the future is terrifying and yet 'fear' is, as we have seen, is also an important emotion required to enact change. As McAdam (2017: 204) noted:

Fear is a tricky emotion. It can paralyze as well as mobilize. Accordingly, climate change activists would be wise not to rely on fear alone to motivate popular concern and action on the issue. The combination of anger and hope has proven to be a powerful motivator in many successful movements. In general, rights movements have traditionally relied on this potent mix of emotions.

In 2020, the pandemic in particular and the mobilisation of the BLM movement to a lesser extent, have given many of those committed to the fight against the climate emergency hope - hope because they have seen that the world can respond, on a global scale, and thus change is possible (Parker 2020). Hope is therefore vitally important. However, there are inherent dangers of hope, not least that rather than mobilising action, it may actually inhibit it, as a distraction from reality (Chandler 2019). As Lindroth \& Sinevaara-Niskanen (2019: 646) note:

The logic here is that, with hope, one can endure dispossession today in anticipation of a reward tomorrow. By reaching to the future, a politics of hope is able to maintain the status quo; where it succeeds in instilling hope, it succeeds in endlessly postponing the materialization of promises. Ultimately, the vision of a brighter future traps those in need in an 'endurance test' of time.

The point here is that unfettered hope can mean that 'faith' in a future possibility without then acting and, 'while allowing us to maintain the illusion that man [sic] still has agential power, lures us to orient ourselves to the future instead of the present. It traps us in an illusion of our (human) agency' (Lindroth \& SinevaaraNiskanen 2019: 647). Thus, the notion of 'complex hope' as used by Grace (1994) in referring to the desire for change in education to effect social justice is a helpful term. Grace (1994: 59) defined complex hope as 'an optimism of the will that recognises the historical and structural difficulties which need to be overcome'. The message of hope here then has to be that change is possible, but for it to be possible, people have to act; as without action, hope becomes an empty gesture that replaces plausible possibility. 
Change will not therefore happen on its own and whilst the previous section set out a range of actions that people can and are doing, without leadership, change will not happen far and fast enough. We cannot simply sit back and 'hope' that the problem will be solved by those who created it - the global status quo most be disrupted. A major issue in mobilising the climate movement, according to McAdam (2017), is the problem of there being no clear 'ownership' of the problem and he suggests that rather than attempting to mobilise a broad movement through a general education campaign, the mobilising enough of those people most at risk of the impacts of climate change should be the strategy within the US. Whilst we agree that 'ownership' is a problem and also agree with McAdam in the identification of the core groups most at risk and therefore most likely to be motivated to mobilise, we offer a slightly different take that a general education campaign should be the goal and that this should be led by those most at risk from the climate crisis. These groups are, we would contend, best placed to understand the problem, communicate it and lead action to effect change. In our view, it is therefore youth, the disadvantaged, Black, Brown and Indigenous people, who are unequivocally those groups most at risk from climate change (Sanson \& Burke 2020; Whyte 2018) and best placed to lead, with many already 'showing the way despite having more barriers to overcome' (Robinson 2019: 143). Leadership in this sense is understood as multifaceted and horizontal (and more distributive). This is important not least because these groups most likely to experience the impacts of climate change (both presently and to come) and yet they are also least likely to have created the problem and least likely to be in national and global leadership roles in traditional political systems. Moreover, these groups are also most likely to be politically disadvantaged by, and feel unrepresented in, most political systems within nation states and are therefore less able to exert political influence, or be ineligible to pressurise governments with their vote. It is well-known that traditional, top-down hierarchal power structures are unequally distributed. In the Global North, they are disproportionately male, white, wealthy and elder, and it is perhaps no coincidence that this also happens to fit the profile of the biggest creators of climate change (Robinson 2019). Therefore 'ownership' of the problem and thus leadership in seeking change cannot not rely on the same mechanisms and the same people that created the problem. The adage 'if you always do what you've always done, you'll always get what you always got' is significant here. Those who 'created' the problem, cannot be entrusted to act. As Shiva (1994: 196) argued, "the "global" does not represent any universal human interest; it represents a particular local and parochial interest that has been globalized through its reach and control' (Shiva 1994: 196).

\footnotetext{
${ }^{1}$ Proverb often attributed to Henry Ford but provenance unclear
} 
Instead, the world needs to be taking its leadership on tackling climate change from those with a significant stake.

The youth-led climate movement is already a beacon of success in beginning to democratise and generate horizontal forms of leadership (Krieger 2020a) and the mass mobilising of climate activism with a teenage girl now the most well-known climate activist in the world. Whilst the pandemic interrupted the climate strikes, the movement has solidified their mastery of using social media to continue to build the movement (Parker 2020). Social media platforms are transforming political engagement by offering actors, in particular a younger generation, significant agency, notably through the opportunity to connect a broader global audience. During the pandemic, youth have witnessed that change is possible, they have seen nation states respond to the COVID-19 crisis, highlighting that action on the climate remains possible (Parker 2020). Youth have also mobilised as part of the BLM movement and are, as we have noted, seeing the parallels between the movements focused on climate justice, social justice and racial justice (Lakhani \& Watts 2020; Thomas \& Haynes 2020).

There is much to be learnt from engaging cross-cultural forms of learning (Head et al. 2018; MacGregor et al. 2019; Walker 2020) and engaging with Indigenous knowledge's (Schlosberg \& Carruthers 2010) in relation to climate change. However, there has been a tendency to position climate action and activism as white and originating in the Global North (Jones 2020). For instance, Burton (2019) notes that with Greta Thunberg positioned as the figurehead of the global youth-led climate movement, 'and by the media and wider public making her the centre of youth-led climate activism, the work of many Indigenous, Black, and Brown youth activists is often erased or obscured'. Such a side-lining of Black, Brown and Indigenous peoples in the imaginary of youth-led climate action was illustrated after the Black Ugandan youth-activist Vanessa Nakate was removed by the Associated Press from a picture that was then widely used showing only the other four, white activists and not referred to at all in coverage after the group of five had given a news conference at the World Economic Forum Annual Meeting in Davos in January 2020 (Evelyn 2020).

Whilst many in the Global North contemplate climate change as something that is still to come, many Indigenous communities have already faced significant environmental damage resulting from climate change (Whyte 2018). However, as IrlbacherFox \& MacNeill (2020: 271-2) note:

... using Indigenous experiences as evidence for climate change is often where the conversation stops - it should instead be a starting point. The conversation needs to turn to how Indigenous Knowledge, cultures, and the ways of life grounding Indigenous decision-making authority are a viable, legitimate, sustainable, and adaptive climate change strategy. 
In addition, Indigenous peoples have also experienced significant environmental damage from colonial violence (Curnow \& Helferty 2018) and epistemic violence (Knopf 2015) enacted upon them. As the world, increasingly turns to Indigenous communities to learn from their wisdom on land guardianship, to avoid their own 'dystopian future', Whyte (2018: 224) argues that the present already feels distinctly dystopian for many Indigenous peoples where 'in some cases, [they] serve as the backdrop for allies' narratives that privilege themselves as the protagonists who will save Indigenous peoples from colonial violence and the climate crisis'. As international groups and organisations seek solutions to the climate and associated biodiversity crises, Indigenous peoples' rights and livelihoods remain at threat. Archana Soreng, an Indigenous youth representative and member of the Secretary-General's Youth Advisory Group on Climate change speaking at the UN's first Global Biodiversity Summit supported the view that Indigenous knowledge and practices are an important tool in mitigating against climate change and that that Indigenous peoples should play an important role decision-making structures for biodiversity conservation (United Nations 2020). Soreng also warned:

Doubling protected areas to cover $30 \%$ of the globe, as some want to see in the Post2020 Global Biodiversity Framework, will lead to immense human rights violations. It could constitute the biggest land grab of world history reducing millions of people to landless poverty - all in the name of conservation. Removing us from our land in order to protect 'nature' is deeply colonial and environmentally damaging. We should be the leaders of Conservation - not victims of it (OMMCOM News 2020).

The point here reminds us that even as attempts are made to mitigate the climate crisis, the negative consequences of these efforts are likely to also be unjust, as they disproportionately impact further upon those communities already affected. It also reminds us of the way in which solutions also run the risk of re-enacting colonial forms of oppression akin to further enclosure. Indigenous peoples have lived upon and managed the lands for time immemorial and their role in leadership in climate action is therefore central. As Irlbacher-Fox \& MacNeill (2020: 273) argue:

In other words, the best climate change adaptation strategy is for governments (and voters) to support Indigenous governance of climate change strategies for their communities and territories, ensuring the provision of resources needed to accomplish targeted outcomes and goals.

Leadership of this kind must remain grounded in lived experience and bound by a core purpose where 'climate change is fundamentally about human rights and securing justice for those suffering from its impact - vulnerable countries and communities that are least culpable for the problem' (Robinson 2019: xii). This lived experience lens is important to humanise climate change as an issue of justice, hopefully helping 
traverse the pitfalls of the image problem of traditional activism in the Global North, including that it has been perceived as endemically middle class and not grounded in the day-to-day struggles of the global poor and working-class communities (Clark 2018; Willis 2020). Leadership must also seek to draw upon a range of critical perspectives that are situated outside normative political processes to assist in holding nations to account by disrupting the status quo. Thus, there is an important role for social and cultural perspectives outside of normative policy making structures, for instance feminism (Haq et al. 2020; Robinson 2019) as well as those whom seek to pose uncomfortable questions about the root causes of climate change as embedded within capitalism (Klein 2014). The COVID-19 pandemic has 'disrupted' people and there is an appetite for positive change as part of the momentum to 'build back better' and this opportunity must now be harnessed.

\section{Summary and conclusions}

The aim of this article was to examine climate action and inaction through applying an emotional framework of loss and drawing upon the ideas of Kübler-Ross (1969). Moreover, the article used this framework but did this through the lens of the year 2020, one that will undoubtedly go down as an unprecedented year of enforced change as a result of the COVID-19 global pandemic. Our purpose in doing this was to understand not only the challenges arising from this tumultuous year of change but also in terms of what could be learnt from the ways in which the pandemic forced a sense of collective loss not previously experienced in modern history. Through this affective framework, the article itself is framed as akin to an emotional journey starting with understanding the need for urgent action but in the context of widespread global inaction. The article addresses the scale of the challenge ahead and argues that to move towards effecting the change needed, climate change must be understood as an issue of human rights and injustice whereby citizens are more able to see the threat of climate change as happening now, in unjust ways and to be contextualised to their own lives. We argued that the year 2020 offers both an important reference point for framing future discussions of climate change and also offers us important insights about the intersectional nature of inequalities and injustice and its role in mobilising citizens into climate action. In building upon the framework of loss, we highlight the important role of hope in mobilising climate action, noting the significance of agency whereby people understand the various ways in which they can engage in action (ranging from making individual change to everyday practices, through to engaging in forms of climate activism and/or social action projects focused on climate adaption/ mitigation) whereby all action is valued and part of a broad-based climate movement. 
Throughout the article, we argued that the disruption brought about by the pandemic is fuelling an appetite for positive change and rebuilding for fairer and more environmentally sustainable futures for all. Finally, remaining with the notion of hope, we suggested that leadership in mobilising wide spread climate action might best be found with those groups who have already experienced and/or perceived climate change as a loss and threat to their futures and as such, are already most engaged with climate action. As we set out in the introduction to the article, whilst climate change is a global issue, systemic climate inaction is largely driven by the Global North as resistance to disrupting our status quo of consumption and success continually tied to economic growth (reliant on increasing power needs including a reliance on fossil fuels). As such, our article inevitably focuses on climate inaction (and the need for mobilisation into action) from this perspective but argues specifically that climate action must go beyond, and pose important challenges to our normative cultural and social roles, expectations and approaches by seeking leadership from those groups usually least empowered globally: young people, Black, Brown and Indigenous peoples and those facing poverty and disadvantage globally and within societies. Thus in recognising that injustice is intersectional, we must also recognise that the responses to these injustices must be similarly intersectional (Jones 2020). It must also be inclusive (Krieger 2020a.) where everyone understands the important role they can, and must, play in effecting positive change thereby creating some sense of ownership which is needed to sustain climate action. But importantly, and in the famous words of Margaret Mead (Lutkehaus 2008: 4):

Never doubt that a small group of thoughtful, committed citizens can change the world; indeed, it's the only thing that ever has.

\section{Acknowledgements}

We are grateful to the British Academy for funding our project 'Youth-Led Adaptation for Climate Change Challenges in Vietnam: Social Action, Inter-Generational and Inter-Cultural Learning', funded as part of the Youth Futures programme.

\section{References}

Albrecht, G., Sartore, G., Connor, L., Higginbotham, N., Freeman, S., Kelly, B., Stain, H., Tonna, A. \& Pollard, G. (2007), 'Solastalgia: The Distress Caused by Environmental Change', Australasian Psychiatry, 15(1): S95-S98. https://doi.org/10.1080/10398560701701288

Antadze, N. (2020), 'Moral Outrage as the Emotional Response to Climate Injustice', Environmental Justice, 13(1): 21-6. https://doi.org/10.1089/env.2019.0038 
Ayling, J. \& Gunningham, N. (2015), 'Non-state governance and climate policy: the fossil fuel divestment movement', Climate Policy, 17: 131-49. https://doi.org/10.1080/14693062.2015.1094729

Bandura, A. \& Cherry, L. (2019), 'Enlisting the power of youth for climate change', The American Psychologist, 75(7): 945-51. https://doi.org/10.1037/amp0000512

Bashir, N.Y., Lockwood, P., Chasteen, A.L., Nadolny, D. \& Noyes, I. (2013), 'The ironic impact of activists: Negative stereotypes reduce social change influence', European Journal of Social Psychology, 43(7): 614-26. https://doi.org/10.1002/ejsp.1983

Berinato, S. (2020), 'That discomfort you're feeling is grief', Harvard Business Review (23 March). Available at https://hbr.org/2020/03/that-discomfort-youre-feeling-is-grief [accessed 13 November 2020].

Bloch, E. (1986), The principle of hope (Cambridge MA, MIT Press).

Cozen, B. (2013), 'Mobilizing Artists: Green Patriot Posters, Visual Metaphors, and Climate change Activism', Environmental Communication, 7(2): 297-314. https://doi.org/10.1080/17524032.2013.777353

Brunton, J. (2020), “Nature is taking back Venice”: wildlife returns to tourist-free city', Guardian (20 March).Availableathttps://www.theguardian.com/environment/2020/mar/20/nature-is-taking-backvenice-wildlife-returns-to-tourist-free-city [accessed 10 November 2020].

Burton, N. (2019), 'Meet the young activists of color who are leading the charge against climate disaster', VOX (11 Oct online). Available at https://www.vox.com/identities/2019/10/11/20904791/youngclimate-activists-of-color [accessed 16 November 2020].

Cagle, S. (2019), “Protesters as terrorists": growing number of states turn anti-pipeline activism into a crime', Guardian (8 July). Available at https://www.theguardian.com/environment/2019/jul/08/ wave-of-new-laws-aim-to-stifle-anti-pipeline-protests-activists-say [accessed 10 November 2020].

Chandler, D. (2019), 'The death of hope? Affirmation in the Anthropocene', Globalizations, 16(5): 695706. https://doi.org/10.1080/14747731.2018.1534466

CIVICUS (2020), State of civil society report 2020. Available at https://www.civicus.org/index.php/state-of-civil-society-report-2020 [accessed 10 November 2020].

Clark, P. (2018), 'Climate change is firing up middle-class activism', Financial Times (9 December). Available at https://www.ft.com/content/4460eb0e-f964-11e8-af46-2022a0b02a6c [accessed 29 October 2020].

Clayton, S. (2020), 'Climate anxiety: Psychological responses to climate change', Journal of Anxiety Disorders, 74: 102263. https://doi.org/10.1016/j.janxdis.2020.102263

Climate Reality Project (2018), 'Four Lessons Psychology Teaches Us about Inspiring Climate Action', Climate Reality Project [Blog] (5 February). Available at https://climaterealityproject.org/blog/ four-lessons-psychology-teaches-us-about-inspiring-climate-action [accessed 5 November 2020].

Climate Reality Project (2020), 'Race and the climate movement: what our Black colleagues want the rest of us to know. Climate Reality Project Statement on Racial Justice', Climate Reality Project [Blog] (19June).Availableathttps://www.climaterealityproject.org/blog/race-and-climate-movement-whatour-Black-colleagues-want-rest-us-know [accessed 10 November 2020].

Cockburn, H. (2020), 'David Attenborough warns coronavirus pandemic is threat to global climate action', Independent (21 October). Available at https://www.independent.co.uk/environment/davidattenborough-greta-thunberg-coronavirus-cop26-covid-19-climate-change-b1201634.html [accessed 02 November 2020].

Coolhart, D., Ritenour, K. \& Grodzinski, A. (2018), 'Experiences of Ambiguous Loss for Parents of Transgender Male Youth: A Phenomenological Exploration', Contemporary Family Therapy, 40: 28-41. https://doi.org/10.1007/s10591-017-9426-x

Corr, C.A. (2019), "The "five stages" in coping with dying and bereavement: strengths, weaknesses and some alternatives', Mortality, 24(4): 405-17. https://doi.org/10.1080/13576275.2018.1527826 
Cunsolo, A. \& Ellis, N.R. (2018), 'Ecological grief as a mental health response to climate change-related loss', Nature Climate Change, 8(4): 275-81. https://doi.org/10.1038/s41558-018-0092-2

Curnow J. \& Helferty, A. (2018), 'Contradictions of solidarity', Environmental Sociology, 9(1): 145-63. https://doi.org/10.3167/ares.2018.090110

DEFRA [Department for Environment, Food and Rural Affairs] (2018), A Green Future: Our 25 Year Plan to Improve the Environment. Available at https://www.gov.uk/government/publications/25-year-environment-plan [accessed 8 November 2020].

DeNicola, E. \& Subramaniam, R. (2014), 'Environmental attitudes and political partisanship', Public Health, 128(5): 404-9. https://doi.org/10.1016/j.puhe.2014.03.005

Dodd, V. \& Grierson, J. (2020), 'Greenpeace included with neo-Nazis on UK counter-terror list', Guardian(17January). Availableathttps://www.theguardian.com/uk-news/2020/jan/17/greenpeaceincluded-with-neo-nazis-on-uk-counter-terror-list [accessed 10 November 2020].

Edgar, A.N. \& Johnson, A.E. (2018), The Struggle over Black Lives Matter and All Lives Matter (London, Lexington Books).

Ekström, M. (1992), 'Causal Explanation of Social Action: The Contribution of Max Weber and of Critical Realism to a Generative View of Causal Explanation in Social Science', Acta Sociologica, 35(2): 107-22. https://doi.org/10.1177/000169939203500203

Evelyn, K. (2020), “Like I wasn't there": climate activist Vanessa Nakate on being erased from a movement', Guardian (29 January) Available at https://www.theguardian.com/world/2020/jan/29/ vanessa-nakate-interview-climate-activism-cropped-photo-davos [accessed 29 October 2020].

Fagan, M. \& Huang, C. (2019), 'A look at how people around the world view climate change', Pew Research Centre (18 April). Available at https://www.pewresearch.org/fact-tank/2019/04/18/ a-look-at-how-people-around-the-world-view-climate-change/ [accessed 10 November 2020].

Farrell, J., McConnell, K. \& Brulle, R. (2019), 'Evidence-based strategies to combat scientific misinformation', Nature Climate change, 9(3): 191-5. https://doi.org/10.1038/s41558-018-0368-6

Fraser, N. (1999), 'Social Justice in the Age of Identity Politics: Redistribution, Recognition and Participation', in L.J. Ray \& A. Sayer (eds), Culture and Economy after the Cultural Turn (London, Sage), 53-75. https://doi.org/10.4135/9781446218112.n2

Friedman, L. (2020), 'Covid, Climate and Denial', New York Times (7 October). Available at https://www.nytimes.com/2020/10/07/climate/covid-climate-and-denial.html [accessed 30 October 2020].

Gerrard, M. (2016), Climate change and human trafficking after the Paris climate agreement (Columbia, Sabin Center for Climate change Law).

Gibson, D.M. (2007), 'The relationship of infertility and death: Using the relational/cultural model of counseling in making meaning', The Humanistic Psychologist, 35(3), 275-89. https://doi.org/10.1080/08873260701415348

Gifford, R. (2011), 'The Dragons of Inaction: Psychological Barriers That Limit Climate change Mitigation and Adaptation', American Psychologist, 66(4): 290-302. https://doi.org/10.1037/a0023566

Givens, J.E., Huang, X. \& Jorgenson, A.K. (2019), 'Ecologically unequal exchange: A theory of global environmental justice', Sociology Compass, 13(5): e12693. https://doi.org/10.1111/soc4.12693

Godin, M. (2020), 'Record Number of Environmental Activists Killed In 2019', Time (29 July). Available at https://time.com/5873137/record-number-killing-environmental-activists-2019/ [accessed on 29 October 2020].

Grace, G. (1994), 'Urban education and the culture of contentment: The politics, culture and economics of inner-city schooling', in N. Stromquist (ed.), Education in urban areas: Cross-national dimensions (Westport, Praeger), 45-59.

Hallegatte, S., Bangalore, M., Bonzanigo, L., Fay, M., Kane, T., Narloch, U., Rozenberg, J., Treguer, D. \& Vogt-Schilb, A. (2015), Shock waves: Managing the impacts of climate change on poverty (Washington DC, World Bank). https://doi.org/10.1596/978-1-4648-0673-5 
Haq, Z.A., Imran, M., Ahmad, S. \& Farooq, U. (2020), 'Environment, Islam, and women: a study of eco-feminist environmental activism in Pakistan', Journal of Outdoor and Environmental Education, 23: 275-91. https://doi.org/10.1007/s42322-020-00065-4

Haque, Z., Becares, L. \& Treloar, N. (2020), Over-Exposed and Under-Protected: The Devastating Impact of COVID-19 on Black and Minority Ethnic Communities in Great Britain. A Runnymede Trust and ICM Survey (London, Runnymede). Available at https://www.runnymedetrust.org/uploads/ Runnymede \%20Covid19\%20Survey\%20report\%20v3.pdf [accessed 13 November 2020].

Head, L., Klocker, N. \& Aguirre-Bielschowsky, I. (2018), 'Environmental Values, Knowledge and Behaviour: Contributions of an Emergent Literature on the Role of Ethnicity and Migration', Progress in Human Geography, 43(3): 397-415. https://doi.org/10.1177/0309132518768407

Hein, J.E. \& Jenkins, C.J. (2017), 'Why does the United States lack a global warming policy? The corporate inner circle versus public interest sector elites', Environmental Politics, 26(1): 97-117. https://doi.org/10.1080/09644016.2016.1244966

Hilton, N. (2019), 'It is no longer acceptable to question climate change. So why is it now mainstream to criticise Extinction Rebellion?', Independent (20 July). Available at https://www.independent.co. uk/voices/extinction-rebellion-protests-summer-uprising-climate-change-policy-exchangea9013421.html [accessed 20 October 2020].

Hobbs, R.J. (2013), 'Grieving for the Past and Hoping for the Future: Balancing Polarizing Perspectives in Conservation and Restoration', Restoration Ecology, 21(2): 145-48.

https://doi.org/10.1111/rec.12014

IPBES [Intergovernmental Science-Policy Platform on Biodiversity and Ecosystem Services] (2019), Report of the plenary of the intergovernmental science-policy platform on biodiversity and ecosystem services on the work of its seventh session (Paris, IPBES).

IPCC [Intergovernmental Panel on Climate change] (2018), Global warming of $1.5^{\circ} \mathrm{C}$ : An IPCC special report on the impacts of global warming of $1.5^{\circ} \mathrm{C}$ above pre-industrial levels and related global greenhouse gas emission pathways, in the context of strengthening the global response to the threat of climate change, sustainable development, and efforts to eradicate poverty (Geneva, IPCC).

IPCC (2021), Climate Change 2021: The Physical Science Basis. Contribution of Working Group I to the Sixth Assessment Report of the Intergovernmental Panel on Climate Change Cambridge: Cambridge University Press.

Irlbacher-Fox, S. \& MacNeill, R. (2020), 'Indigenous Governance is an Adaptive Climate change Strategy', Northern Review, 49: 271-75. https://doi.org/10.22584/nr49.2020.019

Islam, N. \& Winkel, J. (2017), Climate change and social inequality (New York, United Nations).

Jafry, T. (2020), Climate Justice and Inequality in the Wake of the Coronavirus Pandemic, Centre for Climate Justice (16 November). Available at https://www.caledonianblogs.net/climatejustice/ 2020/09/15/climate-justice-and-inequality-in-the-wake-of-the-coronavirus-pandemic/ [accessed 15 October 2020].

Jalagat, R. (2018), 'Reflecting Change in a Changing World: The Human and Spiritual Dimension', European Business \& Management. Special Issue: Change and Change Management: the Path into Coping up with Uncertainties, 4(3-1): 1-5.

Jones, R. (2020), 'The environmental movement is very white. These leaders want to change that', National Geographic (29 July). Available at https://www.nationalgeographic.com/history/2020/07/ environmental-movement-very-white-these-leaders-want-change-that/ accessed 30 October 2020].

Jorgenson, A.K., Fiske, S., Hubacek, K., Li, J., McGovern, T., Rick, T., Schor, J.B., Solecki, W., York, R. \& Zycherman, A. (2019), 'Social science perspectives on drivers of and responses to global climate change', Climate change, 10(1): e554-n/a. https://doi.org/10.1002/wcc.554

Ki-Moon, B. \& Verkooijen, P. (2020), 'As Black Lives Matter puts injustice in spotlight, climate emergency risks new "apartheid", USA Today Opinion (n.d). Available at https://eu.usatoday.com/story/ opinion/2020/08/11/climate-change-cannot-ignored-its-effects-impact-social-inequality-column/ $3331165001 /$ [accessed 16 October 2020]. 
Klein, N. (2014), This changes everything (London, Penguin Books Ltd).

Knopf, K. (2015), 'The Turn Toward the Indigenous: Knowledge Systems and Practices in the Academy Author(s)', American Studies, 60(2/3): 179-200.

Krieger, N. (2020a), 'Climate crisis, health equity, and democratic governance: the need to act together', Journal of Public Health Policy, 41: 4-10. https://doi.org/10.1057/s41271-019-00209-x

Krieger, N. (2020b), 'ENOUGH: COVID-19, Structural Racism, Police Brutality, Plutocracy, Climate change - and Time for Health Justice, Democratic Governance, and an Equitable, Sustainable Future', American Journal of Public Health, 110(11): 1620-23. https://doi.org/10.2105/AJPH.2020.305886

Kübler-Ross, E. (1969) On Death and Dying (New York, Macmillan).

Lakhani, N. \& Watts, J. (2020), 'Environmental justice means racial justice, say activists', Guardian (18 June). Available at https://www.theguardian.com/environment/2020/jun/18/environmental-justicemeans-racial-justice-say-activists [accessed 10 October 2020].

Lally, C. (2020), 'COVID-19 and occupational risk', The Parliamentary Office of Science and Technology (19 October). https://post.parliament.uk/covid-19-and-occupational-risk/ [accessed 6 November 2020].

Larsson, A. (2020), 'Covid and hope: Is this the turning point we've been waiting for?', Greenpeace (28 August). Available at https://www.greenpeace.org/new-zealand/story/covid-hope-is-turning-point/ [accessed 10 November 2020].

Lawson, R. (2020), 'Coronavirus has led to an explosion of new words and phrases - and that helps us cope', The Conversation (28 April). Available at https://theconversation.com/coronavirus-has-ledto-an-explosion-of-new-words-and-phrases-and-that-helps-us-cope-136909 [accessed 19 November 2020].

Lindblom, J. \& Jacobsson, K. (2014), 'A Deviance Perspective on Social Movements: The Case of Animal Rights Activism', Deviant Behavior, 35(2): 133-51. https://doi.org/10.1080/01639625.2013.834751

Lindroth, M. \& Sinevaara-Niskanen, H. (2019), 'Politics of hope', Globalizations, 16(5): 644-8. https://doi.org/10.1080/14747731.2018.1560694

Lockwood, M. (2018), 'Right-wing populism and the climate change agenda: exploring the linkages', Environmental Politics, 27(4): 712-32. https://doi.org/10.1080/09644016.2018.1458411

Lorenzoni, I., Nicholson-Cole, S. \& Whitmarsh, L. (2007), 'Barriers Perceived to Engaging with Climate change among the UK Public and their Policy Implications', Global Environmental Change, 17: 445-59. https://doi.org/10.1016/j.gloenvcha.2007.01.004

Lutkehaus, N.C. (2008), Margaret Mead: The Making of an American Icon (Princetown, Princetown University Press). https://doi.org/10.1515/9780691190273

MacDonald, M. (2020), 'Animals are rewilding our cities. On YouTube, at least', New York Times Magazine (15 April). Available at https://www.nytimes.com/2020/04/15/magazine/quarantineanimal-videos-coronavirus.html [accessed 16 October 2020].

MacGregor, S.,Walker, C. \& Katz-Gerro, T. (2019), “It's What I've Always Done”: Continuity and Change in the Household Sustainability Practices of Somali Immigrants in the UK', Journal of Physical, Human, and Regional Geosciences, 107: 143-53. https://doi.org/10.1016/j.geoforum.2019.09.013

Maddrell A. (2020), 'Bereavement, grief, and consolation: Emotional-affective geographies of loss during COVID-19', Dialogues in Human Geography, 10(2): 107-11. https://doi.org/10.1177/2043820620934947

Malik, N. (2020), 'For a few weeks, Black lives mattered. Now what?', Guardian (21 June). Available at https://www.theguardian.com/commentisfree/2020/jun/21/Black-lives-mattered-revolt-culturaldebate-hostile-establishment [accessed 21 June 2020].

Manzanedo, R.D. \& Manning, P. (2020), 'COVID-19: Lessons for the climate change emergency', The Science of the total environment, 742: 140563. https://doi.org/10.1016/j.scitotenv.2020.140563 
Manzo, K. (2010), 'Beyond polar bears? Re-envisioning climate change', Meteorological Applications, 17(2): 196-208. https://doi.org/10.1002/met.193

Margolin, J. (2020), 'Why the Climate Movement Must Unite Behind the Black Lives Matter Movement', The Elders [Blog] (8 June). Available at https://www.theelders.org/news/why-climate-movementmust-unite-behind-Black-lives-matter-movement [accessed 8 June 2020].

Marshall, N., Adger, W.N., Benham, C., Brown, K., Curnock, M.I., Gurney, G.G. \& Thiault, L. (2019), 'Reef grief: Investigating the relationship between place meanings and place change on the great barrier reef, Australia', Sustainability Science, 14: 579-87. https://doi.org/10.1007/s11625-019-00666-z

Martiskainen, M., Axon, S., Sovacool, B.K., Sareen, S., Furszyfer, D.R.D. \& Axon, K. (2020), 'Contextualizing climate justice activism: Knowledge, emotions, motivations, and actions among climate strikers in six cities', Global Environmental Change, 65: 102180. https://doi.org/10.1016/j.gloenvcha.2020.102180

McAdam, D. (2017), 'Social movement theory and the prospects for climate change activism in the United States', Annual Review of Political Science, 20(1): 189-208. https://doi.org/10.1146/annurev-polisci-052615-025801

McCarthy, J. (2019), 'If Greta's message bothers you, how do you think she feels?', Sunday Times (29 September). Available at https://www.thetimes.co.uk/article/justine-mccarthy-if-greta-s-messagebothers-you-how-do-you-think-she-feels-h52wp7ldk [accessed 13 October 2020].

Mersha, S. (2018), 'Black lives and Climate Justice: Courage and power in defending communities and Mother Earth', Third World Quarterly, 39(7): 1421-34. https://doi.org/10.1080/01436597.2017.1368385

Middeldorp, N. \& Le Billon, P. (2019), 'Deadly environmental governance: Authoritarianism, ecopopulism, and the repression of environmental and land defenders', Null, 109(2): 324-37. https://doi.org/10.1080/24694452.2018.1530586

Moeve, M. (2019), When 4 million people rise up, there is no turning back: use your power. Available at https:/globalclimatestrike.net/when-4-million-people-rise-up-there-is-no-turning-back-use-yourpower-2/ [accessed 29 October 2020].

Morton, T.A., Rabinovich, A., Marshall, D. \& Bretschneider, P. (2011), 'The future that may (or may not) come: How framing changes responses to uncertainty in climate change communications', Global Environmental Change, 21(1): 103-109. https://doi.org/10.1016/j.gloenvcha.2010.09.013

Moser, S.C. (2010), 'Communicating climate change: History, challenges, process and future directions', WIREs Climate change, 1(1): 31-53. https://doi.org/10.1002/wcc.11

Moser, S.C. (2020), 'The work after "it's too late" (to prevent dangerous climate change)', WIREs Climate Change, 11(1): e606. https://doi.org/10.1002/wcc.606

Murray, J. (2020), 'Teaching white privilege as uncontested fact is illegal, minister says', Guardian (20 October). Available at https://www.theguardian.com/world/2020/oct/20/teaching-white-privilegeis-a-fact-breaks-the-law-minister-says [accessed 4 November 2020].

Nabi, R.L., Gustafson A. \& Jensen, R. (2018), 'Framing Climate change: Exploring the Role of Emotion in Generating Advocacy Behavior', Science Communication. 40(4): 442-68. https://doi.org/10.1177/1075547018776019

NASA [National Aeronautics and Space Administration] (2020), Facts: Global temperatures. Global Climate change: Vital Signs of the Planet. Available at https://climate.nasa.gov/news/?page=0\&per page $=40 \&$ order $=$ publish_date + desc $\% 2 C+$ created_at + desc $\&$ search $=\&$ category $=19 \% 2 C 98$ [accessed 11 November 2020].

Norgaard, K. (2012), 'Climate Denial and the Construction of Innocence: Reproducing Transnational Environmental Privilege in the Face of Climate change', Race, Gender \& Class, 19(1/2): 80-103.

Obinger, H., Petersen, K. \& Starke, P. (eds) (2018), Warfare and Welfare: Military Conflict and Welfare State Development in Western Countries, (Oxford, Oxford University Press). https://doi.org/10.1093/oso/9780198779599.001.0001 
O’Brien, K., Selboe, E. \& Hayward, B. (2018), 'Exploring youth activism on climate change: Dutiful, disruptive, and dangerous dissent', Ecology and Society, 23(3): 42. https://doi.org/10.5751/ES-10287-230342

O'Connor, B., Bojinski, S., Röösli, C. \& Schaepman, M.E. (2020), 'Monitoring global changes in biodiversity and climate essential as ecological crisis intensifies', Ecological Informatics, 55. https://doi.org/10.1016/j.ecoinf.2019.101033

Ojala, M. (2015), 'Hope in the face of climate change: Associations with environmental engagement and student perceptions of teachers' emotion communication style and future orientation', Journal of Environmental Education, 46(3): 8. https://doi.org/10.1080/00958964.2015.1021662

OMMCOM News (2020), 'Are World Leaders Ready To Work With Youth, Asks Archana Soreng At UN Biodiversity Summit', OMMCOM News (1 October). Available at https://ommcomnews. com/odisha-news/are-world-leaders-ready-to-work-with-youth-asks-archana-soreng-at-un-biodiversity-summit [accessed 21 October 2020].

OECD [Organisation for Economic Co-operation and Development] (2020), Building back better: A sustainable, resilient recovery after COVID-19. OECD Policy Responses to Coronavirus (COVID19). Available at http://www.oecd.org/coronavirus/policy-responses/building-back-better-asustainable-resilient-recovery-after-covid-19-52b869f5/ [accessed 27 October 2020].

Oxford English Dictionary (2020), 'Activism/Activist'. Available at https://www.oed.com [accessed 16 November 2020].

Parker, L. (2020), 'For young people, two defining events: COVID-19 and climate change', National Geographic (1 May). Available at https://www.nationalgeographic.co.uk/science-and-technology/ 2020/05/young-people-two-defining-events-covid-19-and-climate-change [accessed 4 October 2020].

Parkes, C.M. (1972), Bereavement: Studies of grief in adult life. (New York, International University Press).

Parsons, E.C.M. (2016), “Advocacy” and "Activism” Are Not Dirty Words - How Activists Can Better Help Conservation Scientists', Frontiers in Marine Science, 3(229): 1-6. https://doi.org/10.3389/fmars.2016.00229

Parsons, T. (1937), The structure of social action (New York, McGraw Hill).

Pellow, D. (2016), 'Towards a critical Environmental Justice Studies: Black Lives Matter as an Environmental Justice Challenge', Du Bois Review, 13(2): 221-36. https://doi.org/10.1017/S1742058X1600014X

Peters, G.P., Andrew, R.M., Canadell, J.G., Friedlingstein, P., Jackson, R.B., Korsbakken, J.I. \& Peregon, A. (2020), 'Carbon dioxide emissions continue to grow amidst slowly emerging climate policies', Nature Climate Change, 10(1): 3-6. https://doi.org/10.1038/s41558-019-0659-6

Pihkala, P. (2018), 'Eco-anxiety, tragedy, and hope: Psychological and spiritual dimensions of climate change', Zygon, 53(2): 545-69. https://doi.org/10.1111/zygo.12407

Pinheiro, G. (2020), "Change is coming, whether you like it or not": Greta Thunberg as a threat to the stability of capitalist and patriarchal systems. Available at https://www.justgender.org/change-iscoming-whether-you-like-it-or-not-greta-thunberg-as-a-threat-to-the-stability-of-capitalist-andpatriarchal-systems/ [accessed 30 October 2020].

Poidevin, O. (2020), 'Coronavirus and climate change a "double crisis", BBC News (5 May) Available at https://www.bbc.co.uk/news/av/science-environment-52508829 [accessed 16 November 2020].

Powell, N., Osbeck, M., Tan, S.B. \& Toan, V.C. (2011), Mangrove restoration and rehabilitation for climate change adaptation in Vietnam. World Resources Report Case Study (Washington DC, World Resources Institute).

Prell, C. \& Sun, L. (2015), 'Unequal carbon exchanges: Understanding pollution embodied in global trade', Environmental Sociology, 1(4), 256-67. https://doi.org/10.1080/23251042.2015.1114208 
Ramos-Volz, Y. (2018), “Living Life in the Meantime": An arts-based coaching model offering an alternative method of managing personal and professional change', International Journal of Evidence Based Coaching and Mentoring, 16(1): 143-58.

Reis, P. (2020), 'Environmental Citizenship and Youth Activism', in A. Hadjichambis, P. Reis, D. Paraskeva-Hadjichambi, J. Cincera, J.B. Pauw, N. Gericke \& M.C. Knippels (eds), Conceptualizing Environmental Citizenship for 21st Century Education. Environmental Discourses in Science Education, vol. 4 (Cham, Springer), 139-48. https://doi.org/10.1007/978-3-030-20249-1_9

Reset (2020), Time to Reset. The public desire for a fairer, greener Britain after Covid. A report by the All Party Parliamentary Group on the Green New Deal. Available at https://reset-uk.org/ [accessed 16 November 2020].

Rigaud, K.K., Sherbinin, A., Jones, B., Bergmann, J., Clement, V., Ober, K., Schewe, J., Adamo, S., Mccusker, B., Heuser, S. \& Midgley, A. (2018), Groundswell: Preparing for internal climate migration (World Bank, Washington, DC). https://doi.org/10.1596/29461

Roberts, J.T. \& Parks, B.C. (2007), 'Fuelling Injustice: Globalization, Ecologically Unequal Exchange and Climate change', Globalizations, 4(2): 193-210. https://doi.org/10.1080/14747730701345218

Roberts, M. (2020), 'Coronavirus: Europe experiencing "pandemic fatigue"”, BBC News (6 October). Available at https://www.bbc.co.uk/news/health-54417547 [accessed 3 November 2020].

Robinson, M. (2019), Climate Justice: A man-made problem with a feminist solution (London, Bloomsbury Publishing).

Robinson, M. \& Reddy, D. (2020), Tackling Climate change with COVID-19 Urgency, Project Syndicate (1 April). Available at https://www.project-syndicate.org/commentary/tackling-climate-changewith-covid19-urgency-by-mary-robinson-and-daya-reddy-2020-04 [accessed 9 November 2020].

Roosen, L.J., Klöckner, C.A. \& Swim, J.K. (2018), 'Visual art as a way to communicate climate change: a psychological perspective on climate change-related art', World Art, 8(1): 85-110. https://doi.org/10.1080/21500894.2017.1375002

Rommetveit, K., Funtowicz, S. \& Strand, R. (2010), 'Knowledge, Democracy and Action in Response to Climate change', in R. Bhaskar, C. Frank, K.C. Hoyer, P. Naess \& J. Parker (eds), Interdisciplinarity and Climate change (London, Routledge), 149-63.

Running, S.W. (2007), 'The 5 stages of climate grief', Missoula: Numerical Terradynamic Simulation Group Publications, 173. Available at https://scholarworks.umt.edu/ntsg_pubs/173

Sanders, C. (1999), Grief, the mourning after: Dealing with adult bereavement (2nd edition) (New York, John Wiley). https://doi.org/10.1046/j.1365-2850.1999.00227-5.x

Sanson, A.V. \& Burke, S.E.L. (2020), 'Climate change and Children: An Issue of Intergenerational Justice', in N. Balvin \& D.J. Christie (eds), Children and Peace: From Research to Action (Cham, Springer), 343-62. https://doi.org/10.1007/978-3-030-22176-8_21

Savin-Williams, R. \& Dubé, E. (1998), 'Parental Reactions to Their Child's Disclosure of a Gay/Lesbian Identity', Family Relations, 47(1): 7-13. https://doi.org/10.2307/584845

Schlosberg, D. \& Carruthers, D. (2010), 'Indigenous struggles, environmental justice, and community capabilities', Global Environmental Politics, 10(4): 12-35. https://doi.org/10.1162/GLEP_a_00029

Shiva, V. (1994), 'Conflicts of Global Ecology: Environmental Activism in a Period of Global Reach. Alternatives: Global, Local, Political', Against Global Apartheid: Contemporary Perspectives on World Order and World order Studies, 19(2): 195-207. https://doi.org/10.1177/030437549401900208

Smithers, R. \& Collinson, P. (2020), 'UK supermarkets take steps to prevent panic buying and shortages', Guardian(17 March). Availableathttps://www.theguardian.com/world/2020/mar/17/supermarketstake-steps-to-prevent-coronavirus-panic-buying-and-shortages [accessed 16 November 2020].

Socolow, R.H. (2012), 'Truths We Must Tell Ourselves to Manage Climate change', Vanderbilt Law Review, 65(6): 1455-78. 
Solnit, R. (2020), 'Climate change, Covid - our hearts ache. But a new era is possible. We can do it', Guardian (19 September). Available at https://www.theguardian.com/commentisfree/2020/sep/19/ covid-climate-change- [accessed 16 November 2020].

Staeheli, L.A., Attoh, K. \& Mitchell, D. (2013), 'Contested Engagements: Youth and the Politics of Citizenship', Space and Policy, 17(1): 88-105. https://doi.org/10.1080/13562576.2013.780715

Tannen, D. (ed.) (1993), Framing in Discourse. (Oxford, Oxford University Press).

Taylor-Collins, E., Harrison, T. \& Thoma, S.J. (2019), 'A Habit of Social Action: Understanding the Factors Associated with Adolescents Who Have Made a Habit of Helping Others', Voluntas, 30 : 98-114. https://doi.org/10.1007/s11266-018-00070-8

Taylor, M., Watts, J. \& Bartlett, J. (2019), 'Climate Crisis: 6 million people join latest wave of global protests', Guardian (27 September). Available at www.theguardian.com/environment/2019/sep/27/ climate-crisis-6-million-people-join-latest-wave-of-worldwide-protests [accessed 4 Nov 2020].

Thomas, A. \& Haynes, R. (2020), 'Black Lives Matter: the link between climate change and racial justice', Climate Analytics (22 June). Available at https://climateanalytics.org/blog/2020/Black-livesmatter-the-link-between-climate-change-and-racial-justice/ [accessed 6 November 2020].

Trajber, R., Walker, C., Marchezini, V., Kraftl, P., Olivato, D., Hadfield-Hill, S., Zara, C. \& Fernandes Monteiro, S. (2019), 'Promoting Climate change Transformation with Young People in Brazil: Participatory action research through a looping approach', Action Research, 17(1): 88-107. https://doi.org/10.1177/1476750319829202

Tri, N.H., Adger, W.N. \& Kelly, P.M. (1998), 'Natural resource management in mitigating climate impacts: Mangrove restoration in Vietnam', Global Environmental Change, 8: 49-61. https://doi.org/10.1016/S0959-3780(97)00023-X

UNICEF (2015), Unless We Act Now. The impact of climate change on children (New York, UNICEF).

United Nations (2018), 'Act Now', The UN Campaign for Individual Action. Available at https://www.un.org/en/actnow/ [accessed 13 November 2020].

United Nations (2019), An important opportunity lost as COP25 ends in compromise, but Guterres declares 'we must not give up' (15 December). Available at https://news.un.org/en/story/2019/12/1053561 [accessed 13 October 2020].

United Nations (2020), Make Bold Environmental Action Central Focus of Post Pandemic Economic Recovery, Speakers Urge as General Assembly Holds First Ever Global Biodiversity Summit Online (30 September). Available at https://www.un.org/press/en/2020/ga12274.doc.htm [accessed 28 October 2020].

United Nations Environment Programme (2020), Building Back Better: Why we must think of the next generation (8 May). Available at https://www.unenvironment.org/news-and-stories/story/buildingback-better-why-we-must-think-next-generation [accessed 1 November 2020].

UNFCCC [United Nations Framework Convention on Climate change] (2020), The Paris Agreement (Geneva, United Nations).

United Nations General Assembly (2019), Climate change and poverty: Report of the Special Rapporteur on extreme poverty and human rights (Geneva, United Nations General Assembly).

Vickers, M,H. and Parris, M.A. (2007), "'Your Job No Longer Exists!”: From Experiences of Alienation to Expectations of Resilience - A Phenomenological Study', Employee Responsibilities and Rights Journal, 19: 113-25. https://doi.org/10.1007/s10672-007-9038-y

Walker, C. (2020), "Generation Z" and "Second Generation": An agenda for learning from crosscultural negotiations of the climate crisis in the lives of second generation immigrants', Children's Geographies. https://doi.org/10.1080/14733285.2020.1817334

Ware, T. \& Kramer, K. (2019), Hunger strike: The climate and food vulnerability index (London, Christian Aid). 
Watts, J. (2019), 'Greta Thunberg, schoolgirl climate change warrior: "Some people can let things go. I can't"', Guardian (11 March). Available at https://www.theguardian.com/world/2019/mar/11/ greta-thunberg-schoolgirl-climate-change-warrior-some-people-can-let-things-go-i-cant [accessed 16 October 2020].

Whyte, K. (2018), 'Indigenous science (fiction) for the Anthropocene: Ancestral dystopias and fantasies of climate change crises', Environment and Planning E: Nature and Space, 1(1-2): 224-42. https://doi.org/10.1177/2514848618777621

Williams, J. (2020), What is climate privilege? The Earthbound Report. Available at https://earthbound. report/2020/08/25/what-is-climate-privilege/ [accessed 13 November 2020].

Willis, R. (2020), Too Hot to Handle? The Democratic Challenge of Climate Change (Bristol, Bristol University Press). https://doi.org/10.46692/9781529206036

Wilson, J. (2020), 'How the right is responding to the coronavirus: denial, realism or dangerous contrarianism', Guardian (7 April). Available at https://www.theguardian.com/commentisfree/2020/ apr/07/how-the-right-is-responding-to-the-coronavirus-denial-realism-or-dangerous-contrarianism [accessed 10 September 2020].

Wodak, R. \& Krzyżanowski, M. (2017), 'Right-wing populism in Europe \& USA Contesting politics \& discourse beyond "Orbanism" and "Trumpism", Journal of Language and Politics, 16(4): 471-84. https://doi.org/10.1075/jlp.17042.krz

World Health Organization (2018), Climate change and health. Available at https://www.who.int/newsroom/fact-sheets/detail/climate-change-and-health [accessed 14 September 2020].

WWF (2020), Living Planet Report 2020: Bending the curve of biodiversity loss. Available at https://www.wwf.org.uk/living-planet-report [accessed 16 November 2020].

Wysham, D. (2012). The six stages of climate grief [blog]. Available at http://www.otherwords.org/articles/the_six_stages_of_climate_grief [accessed 20 September 2020]

Zamore, L. \& Phillips, B. (2020) COVID-19 and Public Support for Radical Policies. Available at https:// cic.nyu.edu/sites/default/files/zamore-phillips-covid19-public-support-radical-policies-web-final. pdf [accessed 16 November 2020].

Zeldin-O’Neill, S. (2019) 'Guardian climate pledge 2019. "It's a crisis, not a change”: the six Guardian language changes on climate matters', Guardian (16 October). Available at https://www.theguardian. com/environment/2019/oct/16/guardian-language-changes-climate-environment [accessed on 10 November 2020].

\section{Notes on the authors}

Lisa Jones is a Senior Lecturer in Education at the University of Hull. Her research focuses on issues of disadvantage, inequality and social justice with particular interests in social class, poverty as well as the role of place and space in shaping inequalities. Lisa has a keen interest in creative and participatory research approaches, particularly with young people and disadvantaged groups. https://orcid.org/0000-0001-9463-639X

Florence Halstead is a Research Assistant and part-time PhD student at the University of Hull. She works on a number of research studies that engage children and youth, with a particular focus on Education for Sustainable Development and Climate Resilience. Her PhD project investigates children's perceptions of Climate Change and Flooding in the Mekong Delta and she has an interest in Participatory and Creative Methodologies, Climate Resilience, Social and Climate Justice, Youth Climate Activism and Children's Rights. https://orcid.org/0000-0001-9945-1845 
Katie J. Parsons is a researcher and PhD student at The University of Hull. Her PhD explores the use of the natural environment to raise attainment, wellbeing and pro-environmental behaviours in children and young people within the education system and youth groups. She has a keen interest in climate-related social action and social justice with children and youth and has many ongoing research projects within this field.

https://orcid.org/0000-0002-4980-7206

Hue Le is senior researcher and lecturer from the VNU-Central Institute for Natural Resources and Environmental Studies (CRES), Vietnam National University (VNU), Hanoi. Her research focuses on natural resource management, land tenure, and gender. Her scholarship examines the differentiating effects of the macro policy and investigates how social differentiation and power relations affect the way in which different classes of people use the resources and the income that each class earns from forest-related resources.

https://orcid.org/0000-0003-1130-4272

Ly Thi Ha Bui has 14 years of research expertise working at the Central Institute for Natural Resources and Environmental Studies (CRES), Vietnam National University, Hanoi, as a researcher at the Department of Wetlands, Marine, and Islands Studies. She has a varied range of experiences in working with local authorities, communities, and other civic organisations, such as the Women's Union, Farmers Association, and Youth Union through a range of different projects.

Christopher R Hackney is a NUAcT fellow in Geography, Politics and Sociology at Newcastle University. His research focused on the impacts that climate change and human actions have on water and sediment transport processes through the world's rivers and deltas.

https://orcid.org/0000-0001-5390-9136

Daniel R. Parsons is Director of the Energy and Environment Institute at the University of Hull. His research is focused on the geosciences, with interests in climate change and impacts of earth surface processes, such as flood hazard, and how these change over time.

https://orcid.org/0000-0002-5142-4466

To cite the article: Lisa Jones, Florence Halstead, Katie J. Parsons, Hue Le, Ly Thi Ha Bui, Christopher R. Hackney and Daniel R. Parsons (2021), '2020-Vision: understanding climate (in)action through the emotional lens of loss', Journal of the British Academy, 9(s5): 29-68.

DOI https://doi.org/10.5871/jba/009s5.029

Journal of the British Academy (ISSN 2052-7217) is published by

The British Academy, 10-11 Carlton House Terrace, London, SW1Y 5AH

www.thebritishacademy.ac.uk 